\title{
Chemical characteristics and causes of airborne particulate pollution in warm seasons in Wuhan, central China
}

\author{
Xiaopu Lyu ${ }^{1}$, Nan Chen ${ }^{2}$, Hai Guo ${ }^{1}$, Lewei Zeng ${ }^{1}$, Weihao Zhang ${ }^{3}$, Fan Shen ${ }^{2}$, Jihong Quan ${ }^{2}$, and Nan Wang ${ }^{4}$ \\ ${ }^{1}$ Department of Civil and Environmental Engineering, The Hong Kong Polytechnic University, Hong Kong, Hong Kong \\ ${ }^{2}$ Hubei Provincial Environment Monitoring Center, Wuhan, China \\ ${ }^{3}$ Department of Environmental Sciences, School of Resource and Environmental Sciences, Wuhan University, Wuhan, China \\ ${ }^{4}$ Guangdong Provincial Key Laboratory of Regional Numerical Weather Prediction, Institute of Tropical and Marine \\ Meteorology, Guangzhou, China
}

Correspondence to: Hai Guo (ceguohai@polyu.edu.hk)

Received: 8 January 2016 - Published in Atmos. Chem. Phys. Discuss.: 4 March 2016

Revised: 16 August 2016 - Accepted: 16 August 2016 - Published: 29 August 2016

\begin{abstract}
Continuous measurements of airborne particles and their chemical compositions were conducted in May, June, October, and November 2014 at an urban site in Wuhan, central China. The results indicate that particle concentrations remained at a relatively high level in Wuhan, with averages of $135.1 \pm 4.4$ (mean $\pm 95 \%$ confidence interval) and $118.9 \pm 3.7 \mu \mathrm{g} \mathrm{m}^{-3}$ for $\mathrm{PM}_{10}$ and $81.2 \pm 2.6$ and $85.3 \pm 2.6 \mu \mathrm{g} \mathrm{m}^{-3}$ for $\mathrm{PM}_{2.5}$ in summer and autumn, respectively. Moreover, $\mathrm{PM}_{2.5}$ levels frequently exceeded the $\mathrm{Na}$ tional Standard Level II (i.e., daily average of $75 \mu \mathrm{g} \mathrm{m}^{-3}$ ), and six $\mathrm{PM}_{2.5}$ episodes (i.e., daily $\mathrm{PM}_{2.5}$ averages above $75 \mu \mathrm{g} \mathrm{m}^{-3}$ for 3 or more consecutive days) were captured during the sampling campaign. Potassium was the most abundant element in $\mathrm{PM}_{2.5}$, with an average concentration of $2060.7 \pm 82.3 \mathrm{ng} \mathrm{m}^{-3}$; this finding indicates intensive biomass burning in and around Wuhan during the study period, because almost no correlation was found between potassium and mineral elements (iron and calcium). The source apportionment results confirm that biomass burning was the main cause of episodes 1,3 , and 4, with contributions to $\mathrm{PM}_{2.5}$ of $46.6 \% \pm 3.0 \%, 50.8 \% \pm 1.2 \%$, and $44.8 \% \pm 2.6 \%$, respectively, whereas fugitive dust was the leading factor in episode 2. Episodes 5 and 6 resulted mainly from increases in vehicular emissions and secondary inorganic aerosols, and the mass and proportion of $\mathrm{NO}_{3}^{-}$both peaked during episode 6 . The high levels of $\mathrm{NO}_{x}$ and $\mathrm{NH}_{3}$ and the low temperature during episode 6 were responsible for the increase of $\mathrm{NO}_{3}^{-}$. Moreover, the formation of secondary organic carbon was found to be dominated by aromat-
\end{abstract}

ics and isoprene in autumn, and the contribution of aromatics to secondary organic carbon increased during the episodes.

\section{Introduction}

Airborne particulate pollution, also called "haze", has swept across China in recent years, particularly over its northern, central, and eastern parts (Cheng et al., 2014; Kang et al., 2013; Wang et al., 2013). Due to its detrimental effects on human health (Anderson et al., 2012; Goldberg et al., 2001), the atmosphere (Yang et al., 2012; White and Roberts, 1977), acid precipitation (Zhang et al., 2007; Kerminen et al., 2001), and climate change (Ramanathan et al., 2001; Nemesure et al., 1995), particulate pollution has become a major concern of scientific communities and local governments. China's national ambient air quality standards issued in 2012 regulate the annual upper limit of $\mathrm{PM}_{10}$ (i.e., particulate matter with an aerodynamic diameter of less than $10 \mu \mathrm{m}$ ) and $\mathrm{PM}_{2.5}$ (i.e., particulate matter with an aerodynamic diameter of less than $2.5 \mu \mathrm{m})$ as 70 and $35 \mu \mathrm{g} \mathrm{m}^{-3}$ and $24 \mathrm{~h}$ averages as 150 and $75 \mathrm{\mu g} \mathrm{m}^{-3}$, respectively (GB 3095-2012, 2016).

Numerous studies have been conducted in China to understand the spatiotemporal variations in particle concentrations, the chemical composition, and the causes of haze events (Cheng et al., 2014; Cao et al., 2012; Zheng et al., 2005; Yao et al., 2002). In general, particulate pollution is more severe in winter due to additional emissions (e.g., coal burning) and unfavorable dispersion conditions (Lyu et al., 
2015a; Zheng et al., 2005). Northern China often suffers heavier, longer, and more frequent haze pollution than southern China (Cao et al., 2012). Chemical analysis indicates that secondary inorganic aerosol (SIA; i.e., sulfate $\left[\mathrm{SO}_{4}^{2-}\right]$, nitrate $\left[\mathrm{NO}_{3}^{-}\right]$, and ammonium $\left.\left[\mathrm{NH}_{4}^{+}\right]\right)$and secondary organic aerosol (SOA) dominate the total mass of airborne particles (Zhang et al., 2014, 2012). However, the composition differs among the size-segregated particles. In general, secondary species and mineral or sea salt components are prone to be apportioned in fine and coarse particles (Zhang et al., 2013; Theodosi et al., 2011). Indeed, the general characteristics of particles (e.g., toxicity, radiative forcing, acidity) are all tightly associated with their chemical compositions and physical sizes, which therefore have been extensively studied in the field of aerosols. To better understand and control airborne particulate pollution, the causes and formation mechanisms have often been investigated (Wang et al., 2014a, b; Kang et al., 2013; Oanh and Leelasakultum, 2011). Apart from the unfavorable meteorological conditions, emission enhancement was often the major culprit. There is little doubt that industrial and vehicular emissions contributed greatly to the particle mass via direct emission and secondary formation of particles from gaseous precursors, such as sulfur dioxide $\left(\mathrm{SO}_{2}\right)$, nitrogen oxides $\left(\mathrm{NO}_{x}\right)$, and volatile organic compounds (VOCs; Guo et al., 2011a). In addition, some other sources in specific regions or during specific time periods have also built up the particle concentrations to a remarkable degree, e.g., coal combustion in north China (Cao et al., 2005; Zheng et al., 2005) and biomass burning in Southeast Asia (Deng et al., 2008; Koe et al., 2001). Furthermore, some studies have explored the possible formation mechanisms of the main particle components (SIA and SOA) and distinguished the contributions of different formation pathways. For example, Y. X. Wang et al. (2014) demonstrated that heterogeneous oxidation of $\mathrm{SO}_{2}$ on aerosol surfaces was an important supplementary pathway to particle-bound $\mathrm{SO}_{4}^{2-}$ in addition to gas phase oxidation and reactions in clouds. In contrast, it was reported that homogeneous and heterogeneous reactions dominated the formation of $\mathrm{NO}_{3}^{-}$during the day and night, respectively (Pathak et al., 2011; Lin et al., 2010; Seinfeld and Pandis, 1998). Furthermore, biogenic VOCs and aromatics were shown to be the main precursors of SOA (Kanakidou et al., 2005; Forstner et al., 1997).

Despite numerous studies, the full components of airborne particles have seldom been reported due to the cost of sampling and chemical analysis, resulting in a gap in our understanding of the chemical characteristics of particles. In addition, although the causes of particle episodes have been discussed in many case studies (Y. X. Wang et al., 2014; Deng et al., 2008), the contributions have rarely been quantified. Furthermore, the formation mechanisms might differ in various circumstances. Therefore, an overall understanding of the chemical characteristics of airborne particles, the causes of the particle episodes, and the formation mechanisms of the enhanced species would be of great value. In addition, the frequent occurrence of haze pollution has become a regular phenomenon in central China during warm seasons, but the causes have not been identified and the contributions have not been quantified. Wuhan is the largest megacity in central China and has suffered from severe particulate pollution in recent years. The data indicate that the frequency of days in which $\mathrm{PM}_{2.5}$ exceeded the national standard level II (i.e., a daily average of $75 \mu \mathrm{g} \mathrm{m}^{-3}$ ) in Wuhan reached $55.1 \%$ in 2014 (Wuhan Environmental Bulletin, 2014). In the warm seasons of 2014, the hourly maximum $\mathrm{PM}_{2.5}\left(564 \mu \mathrm{g} \mathrm{m}^{-3}\right)$ was even higher than that in winter $\left(383 \mu \mathrm{g} \mathrm{m}^{-3}\right)$, as shown in Fig. S1 in the Supplement. Moreover, because the air quality in Wuhan is strongly influenced by the surrounding cities, the pollution level in Wuhan also reflects the status of the city clusters in central China. However, previous studies (Lyu et al., 2015a; Cheng et al., 2014) did not allow a complete understanding of the properties of airborne particles in this region, particularly during the warm seasons, nor could they guide control strategies. It is therefore urgent to understand the chemical characteristics of airborne particles and to explore the causes and formation mechanisms of the particle episodes in Wuhan.

This study comprehensively analyzed the chemical characteristics of $\mathrm{PM}_{2.5}$ in Wuhan from a full suite of component measurement data: $\mathrm{SO}_{4}^{2-}, \mathrm{NO}_{3}^{-}, \mathrm{NH}_{4}^{+}$, organic carbon (OC), including primary organic carbon (POC) and secondary organic carbon (SOC), elemental carbon (EC), and elements. Furthermore, based on the analysis of meteorological conditions, chemical signatures, source apportionment, and distribution of wildfires, the causes of the $\mathrm{PM}_{2.5}$ episodes are identified and their contributions quantified. Finally, this study used a photochemical box model incorporating a master chemical mechanism (PBM-MCM) and theoretical calculation to investigate the formation processes of $\mathrm{NO}_{3}^{-}$and SOC. Ours is the first study to quantify the contribution of biomass burning to $\mathrm{PM}_{2.5}$ and examine the formation mechanisms of both inorganic and organic components in $\mathrm{PM}_{2.5}$ in central China.

\section{Methods}

\subsection{Data collection}

The whole set of air pollutants were continuously monitored at an urban site in the largest megacity of central China, i.e., Wuhan. The measurement covered two periods: May and June in summer and October and November in autumn of 2014. The measured species included particle-phase pollutants such as $\mathrm{PM}_{10}, \mathrm{PM}_{2.5}$, and particle-bound components and gas-phase pollutants, including VOCs, $\mathrm{SO}_{2}, \mathrm{CO}$, $\mathrm{NO}, \mathrm{NO}_{2}, \mathrm{O}_{3}, \mathrm{HNO}_{3(\mathrm{~g})}, \mathrm{NH}_{3(\mathrm{~g})}$, and $\mathrm{HCl}_{(\mathrm{g})}$. Hourly data were obtained for each species. The sampling site $\left(30.54^{\circ} \mathrm{N}\right.$, $114.37^{\circ} \mathrm{E}$ ) was located in the Hubei Environmental Moni- 
toring Center Station, as shown in Fig. 1, located in a mixed commercial and residential area in which industries are seldom permitted. The instruments were housed in a room in a six-story building ( $\sim 18 \mathrm{~m}$ above ground level) adjacent to a main road at a straight-line distance of $\sim 15 \mathrm{~m}$. The traffic volume of the road was around 200 vehicles per hour. However, a wall ( $\sim 2 \mathrm{~m}$ high) and several rows of trees ( 7 to $8 \mathrm{~m}$ high) were located between the road and the sampling site.

$\mathrm{PM}_{10}$ and $\mathrm{PM}_{2.5}$ were measured with a continuous ambient particulate monitor (Thermo Fisher-1405D, USA) integrated with a filter dynamics measurement system to minimize the loss of semivolatile particulate matter. The watersoluble ions (WSIs) in $\mathrm{PM}_{2.5}$ and gases including $\mathrm{HNO}_{3}$, $\mathrm{HCl}$, and $\mathrm{NH}_{3}$ were detected with an online ion chromatography monitor (Metrohm-MARGA 1S, Switzerland). However, data were not available in May and June, because the instrument was initially deployed in September. An aerosol OC/EC online analyzer (Sunset-RT-4, USA); the NIOSH thermal-optical transmission method was used to resolve the carbonaceous aerosols (OC and EC). In addition, the elements in $\mathrm{PM}_{2.5}$ were measured with a customized metal analyzer. This instrument used a $\mathrm{PM}_{2.5}$ impactor to collect the airborne particulate samples, which were analyzed by the $\beta$-ray in terms of mass concentrations. The filters loaded with particles were then sent to an X-ray fluorescence analysis system for quantitative analysis. $\mathrm{K}^{+}$monitored by the online ion chromatography correlated well $\left(R^{2}=0.88\right.$; slope $=0.80$ ) with $\mathrm{K}$ monitored by the customized metal analyzer. To keep consistency with other elements, K rather than $\mathrm{K}^{+}$was used to do the following analyses in this study. For the analysis of trace gases $\left(\mathrm{SO}_{2}, \mathrm{CO}, \mathrm{NO}, \mathrm{NO}_{2}\right.$, and $\left.\mathrm{O}_{3}\right)$, we used a suite of commercial analyzers developed by Thermo Environmental Instruments Inc., which have been described in detail (Lyu et al., 2016; Geng et al., 2009). Furthermore, a gas chromatography-flame ionization detector-mass spectrometry system (TH_PKU-300) was used to resolve the real time data of the ambient VOCs. The details of the analysis techniques, resolution, detection limits, and the protocol of quality assurance/control were provided by Lyu et al. (2016) and H. L. Wang et al. (2014).

\subsection{Theoretical calculation and model simulation}

Theoretical calculation and model simulation were applied in this study to examine the formation mechanisms of $\mathrm{NO}_{3}^{-}$and SOC. The particle-bound $\mathrm{NO}_{3}^{-}$was generally combined with $\mathrm{NH}_{3}$ or presented as $\mathrm{HNO}_{3}$ in the ammonia-deficient environment, following the processes described in Reaction (R1) through Reaction (R3) after $\mathrm{HNO}_{3}$ was formed by the oxidation of $\mathrm{NO}_{x}$ (Pathak et al., 2011; Lin et al., 2010). The production of $\mathrm{NO}_{3}^{-}$can be calculated with Eqs. (1)-(4).

$$
\begin{aligned}
& \mathrm{NH}_{3(\mathrm{~g})}+\mathrm{HNO}_{3(\mathrm{~g})} \leftrightarrow \mathrm{NH}_{4} \mathrm{NO}_{3(\mathrm{~s})} k_{1} \\
& \quad=\exp [118.87-24084 / T-6.025 \ln (T)]\left(\mathrm{ppb}^{2}\right)
\end{aligned}
$$

$$
\begin{aligned}
& \mathrm{NH}_{3(\mathrm{~g})}+\mathrm{HNO}_{3(\mathrm{~g})} \leftrightarrow \mathrm{NH}_{4}^{+}+\mathrm{NO}_{3}^{-} k_{2} \\
& \quad=\left(P_{1}-P_{2}\left(1-a_{w}\right)+P_{3}\left(1-a_{w}\right)^{2}\right) \\
& \quad \times\left(1-a_{w}\right)\left(1-a_{w}\right)^{1.75} k_{1}\left(\mathrm{ppb}^{2}\right) \\
& \quad \mathrm{N}_{2} \mathrm{O}_{5}+\mathrm{H}_{2} \mathrm{O} \rightarrow 2 \mathrm{HNO}_{3} k_{3} \\
& \quad=\gamma / 4\left(8 k T / \pi m_{\mathrm{N}_{2} \mathrm{O}_{5}}\right) 0.5 A_{p}\left(\mathrm{~s}^{-1}\right) \\
& \ln \left(P_{1}\right)=-135.94+8763 / T+19.12 \ln (T) \\
& \ln \left(P_{2}\right)=-122.65+9969 / T+16.22 \ln (T) \\
& \ln \left(P_{3}\right)=-182.61+13875 / T+24.46 \ln (T) \\
& {\left[\mathrm{NO}_{3}^{-}\right]=0.775} \\
& \quad\left(\frac{\left[\mathrm{NH}_{3}\right]+\left[\mathrm{HNO}_{3}\right]-\sqrt{\left(\left[\mathrm{NH}_{3}\right]+\left[\mathrm{HNO}_{3}\right]\right)^{2}-4\left(\left[\mathrm{NH}_{3}\right]\left[\mathrm{HNO}_{3}\right]-k_{1}\left(k_{2}\right)\right)}}{2}\right)
\end{aligned}
$$

where Reactions (R1) and (R2) describe the homogeneous formation of $\mathrm{NO}_{3}^{-}$in humidity conditions lower and higher than the deliquescence relative humidity of $\mathrm{NH}_{4} \mathrm{NO}_{3}$ (i.e., $62 \%$; Tang and Munkelwitz, 1993), respectively. Reaction (R3) presents the heterogeneous reaction of $\mathrm{N}_{2} \mathrm{O}_{5}$ on the preexisting aerosol surfaces. $k_{1-3}$ represents the rate of Reactions (R1)-(R3). $T, a_{w}$, and $P$ are the temperature, the relative humidity, and the temperature-related coefficient, respectively. In Reaction (R3), $\gamma$ is the reaction probability of $\mathrm{N}_{2} \mathrm{O}_{5}$ on aerosol surfaces, assigned as 0.05 and 0.035 on the surface of sulfate ammonia and element carbon, respectively (Aumont et al., 1999; Hu and Abbatt, 1997). $k$ is the Boltzmann constant $\left(1.38 \times 10^{-23}\right), m_{\mathrm{N}_{2} \mathrm{O}_{5}}$ is the molecular mass of $\mathrm{N}_{2} \mathrm{O}_{5}\left(1.79 \times 10^{-22} \mathrm{~g}\right)$, and $A_{p}$ is the aerosol specific surface area $\left(\mathrm{cm}^{2} \mathrm{~cm}^{-3}\right)$.

Furthermore, the PBM-MCM model was used to simulate the oxidation products in this study, i.e., $\mathrm{O}_{3}, \mathrm{~N}_{2} \mathrm{O}_{5}$, the semi-volatile oxidation products of VOCs (SVOCs), and radicals such as $\mathrm{OH}, \mathrm{HO}_{2}$, and $\mathrm{RO}_{2}$. With full consideration of photochemical mechanisms and real meteorological conditions, the model has been successfully applied in the study of photochemistry. Details about the model construction and application were published by Lyu et al. (2015b), Ling et al. (2014), and Lam et al. (2013).

\subsection{Source apportionment model}

The positive matrix factorization (PMF) model (EPA PMF v5.0) was used to resolve the sources of $\mathrm{PM}_{2.5}$. As a receptor model, PMF has been extensively used in the source apportionment of airborne particles and VOCs (Brown et al., 2007; Lee et al., 1999). Detailed introductions of the model can be found in Paatero (1997) and Paatero and Tapper (1994). Briefly, it decomposes the input matrix (X) into matrices of factor contribution $(\mathbf{G})$ and factor profile $(\mathbf{F})$ in $p$ sources, as shown in Eq. (5). The hourly concentrations of $\mathrm{PM}_{2.5}$ components were included in the input matrix. Values below the detection limit (DL; see Table S1 in the Supplement) were replaced with DL/2. The uncertainties were 


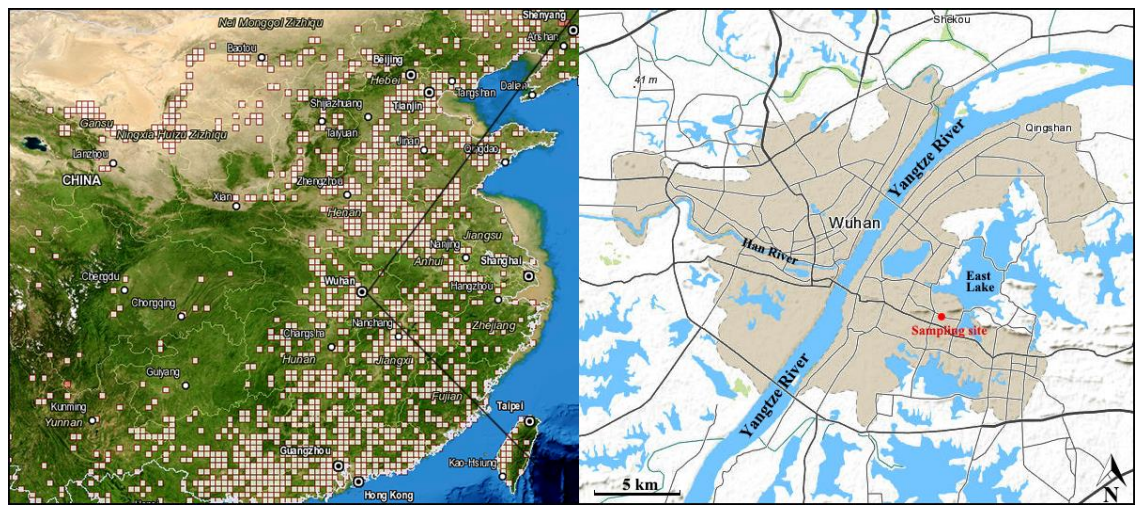

Figure 1. Geographic location of the sampling site. White blocks in left panel represent total distribution of wildfires in autumn 2014, and urban area in Wuhan is highlighted in gray in the right panel.

$\sqrt{(10 \% \times \text { concentration })^{2}+\mathrm{DL}^{2}}$ and $5 / 6 \times$ DL for the samples with concentrations higher and lower than DL, respectively. The signal-to-noise $(S / N)$ ratios were all greater than 1 , indicating "good" signal for all the species involved in source apportionment, according to the PMF 5.0 User Guide. Samples with any missing values were excluded. In total, 807 and 806 samples were applied for source apportionment in summer and autumn, respectively.

The selection of the factor number and the best solution depended upon the following criteria. (1) A lower $Q$ value (Eq. 6; a function to evaluate the model runs) was preferable. (2) The ratio between $Q_{\text {robust }}$ and $Q_{\text {true }}$ was lower than 1.5. In this study, the ratios were 0.8 and 0.9 for the summer and autumn data simulation, respectively. (3) Good agreement was shown between the predicted and observed $\mathrm{PM}_{2.5}$. The slope and correlation coefficient $\left(R^{2}\right)$ for the linear regression were 0.91 and 0.86 in summer and 0.95 and 0.98 in autumn, respectively, as shown in Fig. S2 in the Supplement. The lower $R^{2}$ value seen during the summer might be due to the lack of WSI data. (4) The residuals were normally distributed between -3 and 3 . Table $\mathrm{S} 2$ summarizes the percentage of samples with residuals between -3 and 3 for each species; the lowest percentages were 92.9 and $96.0 \%$ for $\mathrm{Ni}$ in summer and autumn, respectively. The scaled residuals for $\mathrm{PM}_{2.5}$ are shown in Fig. S3 in the Supplement. The percentage of residuals between -3 and 3 was comparable between summer $(97.5 \%)$ and autumn (98.1\%). Data points not confirming to the residual range $(-3$ to +3$)$ were removed from the analysis. Finally (5), no correlation was found between the factors, which was achieved by examining the G-space plots and controlled by the FPEAK model runs. Figures S4 and S5 in the Supplement present the G-space plots in summer and autumn, respectively. The low factor contributions and poor correlations indicated that rotational ambiguity was effectively controlled.

A bootstrap method was used to estimate the model errors, according to which $95 \%$ confidence intervals (CIs) were calculated. The $95 \% \mathrm{CI}$ for $\mathrm{PM}_{2.5}$ was $0.6 \mu \mathrm{g} \mathrm{m}^{-3}(0.7 \%$ of predicted $\mathrm{PM}_{2.5}$ ) in summer and $2.6 \mu \mathrm{g} \mathrm{m}^{-3}$ (3.2\% of predicted $\mathrm{PM}_{2.5}$ ) in autumn.

$$
\begin{aligned}
& x_{i j}=\sum_{k=1}^{p} g_{i k} f_{k j}+e_{i j} \\
& Q=\sum_{i=1}^{n} \sum_{j=1}^{m}\left[\frac{x_{i j}-\sum_{k=1}^{p} g_{i k} f_{k j}}{u_{i j}}\right]^{2},
\end{aligned}
$$

where $x_{i j}$ and $u_{i j}$ are the concentration and uncertainty of $j$ species (total of $m$ ) in $i$ sample (total of $n$ ), $g_{i k}$ represents the contribution of $k$ th source to $i$ sample, $f_{k j}$ indicates the fraction of $j$ species in $k$ th source, and $e_{i j}$ is the residual for $j$ species in the $i$ sample.

\section{Results and discussion}

\subsection{Concentrations of $\mathbf{P M}_{10}$ and $\mathbf{P M}_{2.5}$}

Table 1 shows the mean concentrations of $\mathrm{PM}_{10}$ and $\mathrm{PM}_{2.5}$ in Wuhan and other Chinese cities and regions. The mean, maximum and minimum values, and standard deviation or $95 \%$ CI were provided if available. In general, the concentrations of airborne particles in Wuhan $\left(135.1 \pm 4.4\right.$ and $118.9 \pm 3.7 \mu \mathrm{g} \mathrm{m}^{-3}$ for $\mathrm{PM}_{10} ; 81.2 \pm 2.6$ and $85.3 \pm 2.6 \mu \mathrm{g} \mathrm{m}^{-3}$ for $\mathrm{PM}_{2.5}$ in summer and autumn, respectively) were lower than those in northern China (i.e., Beijing and Xi' an), comparable to those in eastern China (i.e., Shanghai and Nanjing), and higher than those in southern China (i.e., Guangzhou and Hong Kong) and Taiwan. Bearing in mind that the sampling site, period, method, and instrument all interfere with comparisons, the ambient particulate pollution in Wuhan was severe.

From summer to autumn, $\mathrm{PM}_{10}$ levels declined considerably from $135.1 \pm 4.4$ to $118.9 \pm 3.7 \mu \mathrm{g} \mathrm{m}^{-3}$, whereas $\mathrm{PM}_{2.5}$ remained statistically stable $(p>0.05)$. The higher 

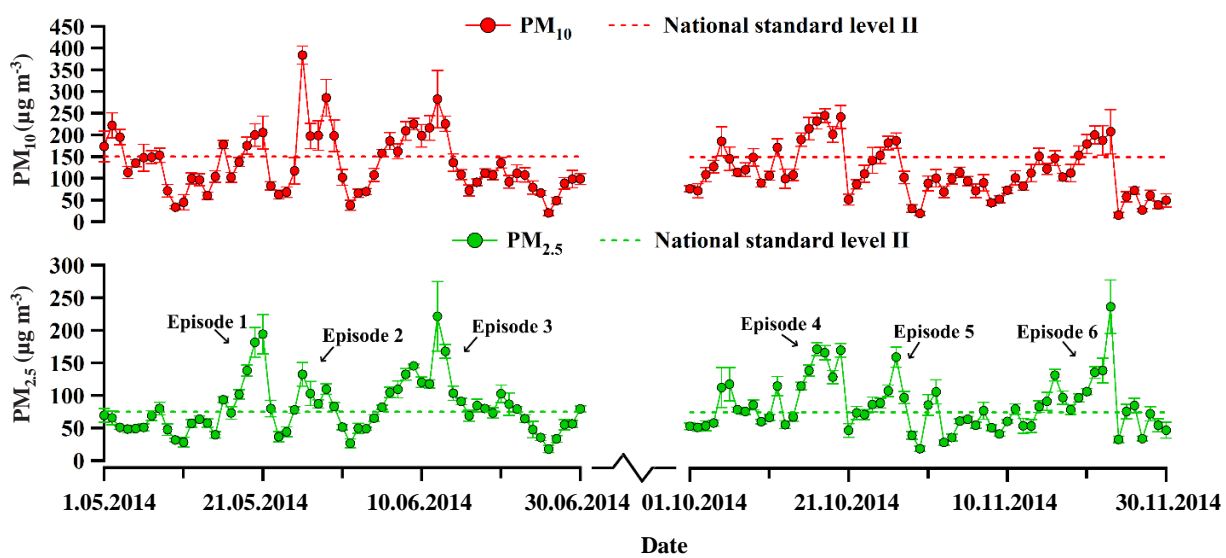

Figure 2. Daily concentrations of $\mathrm{PM}_{10}$ and $\mathrm{PM}_{2.5}$ in May, June, October, and November 2014. Episode 1, 16 to 22 May; episode 2, 25 to 30 May; episode 3, 5 to 15 June; episode 4, 15 to 20 October; episode 5, 24 to 28 October; Episode 6, 14 to 23 November.

Table 1. Comparisons of $\mathrm{PM}_{10}$ and $\mathrm{PM}_{2.5}$ (in $\mu \mathrm{g} \mathrm{m}{ }^{-3}$ ) between Wuhan and other Chinese cities and regions.

\begin{tabular}{lrrl}
\hline & $\mathrm{PM}_{10}$ & PM $_{2.5}$ & Sampling period \\
\hline Wuhan & $135.1 \pm 4.4^{1}$ & $81.2 \pm 2.6^{1}$ & May-Jun 2014 (this study) \\
& $118.9 \pm 3.7^{1}$ & $85.3 \pm 2.6^{1}$ & Oct-Nov 2014 (this study) \\
Beijing & $155.9^{2}$ & $73.8^{2}$ & Jun-Aug 2009 \\
& $194.4^{2}$ & $103.9^{2}$ & Sep-Nov 2009 \\
& $133.7 \pm 87.8^{\mathrm{a}}$ & $71.5 \pm 53.6^{3}$ & 2012 whole year \\
Xi'an & $257.8 \pm 194.7^{3}$ & $140.9 \pm 108.9^{3}$ & 2011 whole year \\
Shanghai & 97.4 to $149.2^{4}$ & 62.3 to $103.1^{4}$ & Jul 2009-Sep 2010 \\
Nanjing & 119 to $171^{4}$ & 87 to $125^{4}$ & Jun 2012 \\
Guangzhou & $23.4^{2}$ & $19.2^{2}$ & Jun-Aug 2010-2013 \\
& $51.0^{2}$ & $41.3^{2}$ & Sep-Nov 2010-2013 \\
Hong Kong & $31.0 \pm 16.7^{\mathrm{f}}$ & $17.7 \pm 12.9^{3}$ & Jun-Aug 2014 \\
& $55.8 \pm 23.6^{3}$ & $34.0 \pm 17.3^{3}$ & Sep-Nov 2014 \\
Taiwan & $39.5 \pm 11.6^{3}$ & $21.8 \pm 7.5^{3}$ & May-Nov 2011 \\
\hline
\end{tabular}

${ }^{1}$ mean $\pm 95 \%$ confidence interval; ${ }^{2}$ arithmetic mean; ${ }^{3}$ mean \pm standard deviation; ${ }^{4}$ range. ${ }^{\text {a }}$ Liu et al. (2014); ${ }^{\mathrm{b}}$ Liu et al. (2015); ${ }^{\mathrm{c}}$ Wang et al. (2015); ${ }^{\mathrm{d}}$ Wang et al. (2013); ${ }^{\mathrm{e}}$ Shen et al. (2014); ${ }^{\mathrm{f}}$ Deng et al. (2015); ${ }^{\mathrm{g}}$ HKEPD (2014); ${ }^{\mathrm{h}}$ Gugamsetty et al. (2012).

summer $\mathrm{PM}_{10}$ concentration was probably related to a higher load of fugitive dust. In Wuhan, the temperature $\left(25.6^{\circ} \mathrm{C} \pm 0.2^{\circ} \mathrm{C}\right)$ in summer was considerably higher than that $\left(17.5^{\circ} \mathrm{C} \pm 0.3^{\circ} \mathrm{C}\right)$ in autumn $(p<0.05)$, which led to lower water content in the soil and a higher tendency of dust suspension. In addition, the average wind speed in summer $\left(1.2 \pm 0.04\right.$ vs. $0.8 \pm 0.03 \mathrm{~m} \mathrm{~s}^{-1}$ in autumn) was also higher $(p<0.05)$, which could also have favored the generation of fugitive dust.

Figure 2 presents the daily concentrations of $\mathrm{PM}_{10}$ and $\mathrm{PM}_{2.5}$ during the sampling period in Wuhan, with the National Standard Level II (daily averages of 150 and $75 \mu \mathrm{g} \mathrm{m}^{-3}$ for $\mathrm{PM}_{10}$ and $\mathrm{PM}_{2.5}$, respectively). It was found that the concentrations of $\mathrm{PM}_{10}$ and $\mathrm{PM}_{2.5}$ frequently exceeded the standard levels, indicating the significance of ambient particulate pollution in Wuhan. Because smaller particles tend to pose more harm to human health and to the atmosphere due to their larger specific surface areas (Yang et al., 2012; Goldberg et al., 2001), and because the chemical compositions in $\mathrm{PM}_{10}$ were not analyzed, this study focused mainly on $\mathrm{PM}_{2.5}$. During the sampling campaign, six $\mathrm{PM}_{2.5}$ episodes, named episodes 1 through 6, with daily averages of $\mathrm{PM}_{2.5}$ in excess of $75 \mu \mathrm{g} \mathrm{m}^{-3}$, were captured (Fig. 2). It should be noted that to ensure the data size of each episode, only the cases in which the daily $\mathrm{PM}_{2.5}$ average was consecutively higher than $75 \mu \mathrm{g} \mathrm{m}^{-3}$ for 3 days or longer were treated as $\mathrm{PM}_{2.5}$ episodes.

Table 2 summarizes the concentrations of $\mathrm{PM}_{10}$ and $\mathrm{PM}_{2.5}$ and the percentage of $\mathrm{PM}_{2.5}$ in $\mathrm{PM}_{10}$, referred to as $\mathrm{PM}_{2.5} / \mathrm{PM}_{10}$, during the summer and autumn episodes and non-episodes. $\mathrm{PM}_{10}$ and $\mathrm{PM}_{2.5}$ concentrations increased significantly $(p<0.05)$ during the episodes in both summer 
Table 2. Mean $\mathrm{PM}_{10}, \mathrm{PM}_{2.5}$, and $\mathrm{PM}_{2.5} / \mathrm{PM}_{10}$ with $95 \% \mathrm{CI}$ during $\mathrm{PM}_{2.5}$ episodes and non-episodes in Wuhan. Non-episode 1 and Non-episode 2 represent the non-episode periods in summer and autumn, respectively. The values during non-episodes were in bold to facilitate comparison.

\begin{tabular}{lrrr}
\hline & $\begin{array}{r}\mathrm{PM}_{10} \\
\left(\mu \mathrm{g} \mathrm{m}^{-3}\right)\end{array}$ & $\begin{array}{r}\mathrm{PM}_{2.5} \\
\left(\mu \mathrm{g} \mathrm{m}^{-3}\right)\end{array}$ & $\begin{array}{r}\mathrm{PM}_{2.5} / \mathrm{PM}_{10} \\
(\%)\end{array}$ \\
\hline Episode 1 & $154.3 \pm 10.1$ & $123.0 \pm 9.1$ & $72.8 \pm 2.6$ \\
Episode 2 & $230.1 \pm 19.1$ & $98.9 \pm 5.7$ & $45.9 \pm 2.5$ \\
Episode 3 & $191.4 \pm 9.8$ & $126.7 \pm 7.0$ & $66.9 \pm 1.8$ \\
Non-episode 1 & $\mathbf{9 8 . 5} \pm \mathbf{3 . 9}$ & $\mathbf{5 6 . 6} \pm \mathbf{1 . 7}$ & $\mathbf{5 8 . 9} \pm \mathbf{1 . 5}$ \\
Episode 4 & $221.8 \pm 8.9$ & $148.6 \pm 5.2$ & $67.9 \pm 2.0$ \\
Episode 5 & $154.2 \pm 10.4$ & $108.2 \pm 6.8$ & $69.3 \pm 3.1$ \\
Episode 6 & $157.3 \pm 9.0$ & $120.0 \pm 7.6$ & $71.2 \pm 2.1$ \\
Non-episode 2 & $\mathbf{8 8 . 7} \pm \mathbf{3 . 4}$ & $\mathbf{6 4 . 2} \pm \mathbf{2 . 2}$ & $\mathbf{6 5 . 3} \pm \mathbf{1 . 3}$ \\
\hline
\end{tabular}

and autumn. The $\mathrm{PM}_{2.5} / \mathrm{PM}_{10}$ value also increased remarkably on episode days compared to that on non-episode days, except for episode $2(45.9 \% \pm 2.5 \%)$, which suggests that more secondary species and/or primary fine particles (e.g., primary OC and EC generated from combustion) were generated or released during the episodes. In contrast, the lower $\mathrm{PM}_{2.5} / \mathrm{PM}_{10}$ value during episode 2 might imply a strong source of coarse particles. Indeed, this inference was confirmed by the source apportionment analysis in Sect. 3.3.3.

\subsection{Chemical composition of $\mathbf{P M}_{2.5}$}

Figure 3 shows the daily variations of $\mathrm{PM}_{2.5}$ and its composition. As the instrument for the analysis of WSIs was initially deployed in September 2014, data are not available for May and June. The carbonaceous aerosol $\left(18.5 \pm 1.2 \mu \mathrm{g} \mathrm{m}^{-3}\right)$ and elements $\left(6.0 \pm 0.3 \mu \mathrm{g} \mathrm{m}^{-3}\right)$ accounted for $19.1 \% \pm 0.6 \%$ and $6.2 \% \pm 0.2 \%$ of $\mathrm{PM}_{2.5}$ in summer, respectively. In autumn, WSIs were the most abundant component in $\mathrm{PM}_{2.5}\left(64.4 \pm 2.5 \mu \mathrm{g} \mathrm{m}^{-3} ; 68.6 \% \pm 1.9 \%\right)$, followed by carbonaceous aerosol $\left(24.3 \pm 1.0 \mathrm{\mu g} \mathrm{m}^{-3} ; 25.5 \% \pm 0.8 \%\right)$ and elements $\left(4.5 \pm 0.2 \mu \mathrm{g} \mathrm{m}^{-3} ; 4.6 \% \pm 0.1 \%\right)$. The secondary inorganic ions $\mathrm{SO}_{4}^{2-}\left(18.8 \pm 0.6 \mu \mathrm{g} \mathrm{m}^{-3}\right), \mathrm{NO}_{3}^{-}$ $\left(18.7 \pm 0.8 \mu \mathrm{g} \mathrm{m}^{-3}\right)$, and $\mathrm{NH}_{4}^{+}\left(12.0 \pm 0.4 \mu \mathrm{g} \mathrm{m}^{-3}\right)$ dominated the WSIs, with the average contribution of $34.0 \% \pm 0.6 \%, 30.1 \% \pm 0.5 \%$, and $20.4 \% \pm 0.1 \%$, respectively.

The charge balance between the anions and cations was usually used to predict the existing forms of SIAs and the acidity of $\mathrm{PM}_{2.5}$. Figure 4 shows the relative abundance of molar charges of SIAs, which were located fairly close to the one-to-one line on both episode and non-episode days. This finding suggests that $\mathrm{NH}_{4} \mathrm{NO}_{3}$ and $\left(\mathrm{NH}_{4}\right)_{2} \mathrm{SO}_{4}$ were coexisting forms of the SIAs in $\mathrm{PM}_{2.5}$ in Wuhan. When extending $\mathrm{NH}_{4}^{+}$to total cations $\left(\mathrm{NH}_{4}^{+}, \mathrm{Ca}^{2+}, \mathrm{Mg}^{2+}, \mathrm{Na}^{+}\right.$, and $\left.\mathrm{K}^{+}\right)$ and $\mathrm{NO}_{3}^{-}$and $\mathrm{SO}_{4}^{2-}$ to total anions $\left(\mathrm{NO}_{3}^{-}, \mathrm{SO}_{4}^{2-}\right.$, and $\left.\mathrm{Cl}^{-}\right)$, the molar charges of the cations and anions were balanced (slope, 0.98; $R^{2}=0.98$ ), as shown in Fig. S6 in the Supplement, indicating that $\mathrm{PM}_{2.5}$ was neutralized during autumn in Wuhan.

For the carbonaceous aerosol, OC $\left(14.8 \pm 0.5 \mu \mathrm{g} \mathrm{m}^{-3}\right)$ and EC $\left(3.6 \pm 0.1 \mu \mathrm{g} \mathrm{m}^{-3}\right)$ accounted for $79.9 \% \pm 0.3 \%$ and $20.2 \% \pm 0.3 \%$ of the total carbon, respectively. In general, SOC was expected to exist when the OC/EC ratio was greater than 2 (Duan et al., 2005; Chow et al., 1996), and the proportion of SOC increased with the increase in OC / EC ratio. The average OC / EC ratio was $4.8 \pm 0.1$ in Wuhan, which suggests that SOC (i.e., carbon fraction of SOA) was an important component in $\mathrm{PM}_{2.5}$. Indeed, as the constituents of OC, SOC and POC can be distinguished with the ECtracer method, following Eqs. (7) and (8) (Cabada et al., 2004):

$\mathrm{POC}=(\mathrm{OC} / \mathrm{EC})_{\text {prim }} \times \mathrm{EC}+\mathrm{OC}_{\text {non-comb }}$

$\mathrm{SOC}=\mathrm{OC}-\mathrm{POC}$,

where $(\mathrm{OC} / \mathrm{EC})_{\text {prim }}$ was the ratio of primary $\mathrm{OC}$ to $\mathrm{EC}$, obtained from the pairs of OC and EC with the OC / EC ratios among the $10 \%$ lowest; and $\mathrm{OC}_{\text {non-comb }}$ was the primary OC that was not related to combustion activities. These values were determined by the slope and intercept of the linear regression between primary OC and EC, respectively (Fig. 5). Because the abundance of SOC depended largely upon the oxidative capacity of the atmosphere, the oxidative radical $\left(\mathrm{HO}_{2}\right)$ was simulated with the PBM-MCM model and compared with the pattern of SOC. More details about the simulation are provided in Sect. 3.4. Figure 6 shows the hourly concentrations of SOC and POC and the average diurnal patterns of SOC, POC, and $\mathrm{HO}_{2}$. In general, the POC levels $\left(8.6 \pm 0.2 \mu \mathrm{g} \mathrm{m}^{-3}\right)$ were slightly higher than those of SOC $\left(6.4 \pm 0.3 \mu \mathrm{g} \mathrm{m}^{-3} ; p<0.05\right)$. The difference was greatest in November, when the concentration was $9.5 \pm 0.4$ and $4.7 \pm 0.3 \mu \mathrm{g} \mathrm{m}^{-3}$ for POC and SOC, respectively. Because the production of SOC was closely related to the atmospheric oxidative capacity, the lowest fraction of SOC in November might be attributable to the weakest oxidative capacity; for example, the $\mathrm{O}_{3}$ level was lowest in November $(14.3 \pm 1.0 \mathrm{ppbv})$. Two peaks were found for the simulated diurnal pattern of $\mathrm{HO}_{2}$, which might be caused by strong solar radiation at noon and in the early afternoon and by reactions among alkenes and $\mathrm{O}_{3}$ and $\mathrm{NO}_{3}$ at night (Emmerson et al., 2005; Kanaya et al., 1999). The diurnal patterns of POC and SOC revealed that POC levels were relatively stable throughout the day. The increase in the POC level in the early morning (06:00 to 08:00 local time (LT)) and late afternoon and early evening (16:00 to 20:00) was likely related to increases in vehicular emissions during rush hours, and the decrease from 08:00 to 15:00 might be caused by the extension of the boundary layer. In contrast, the SOC level showed two peaks at around 12:00 and 19:00, which was consistent with the diurnal variation of the simulated $\mathrm{HO}_{2}$, suggesting that the formation of SOC was closely related to the oxida- 


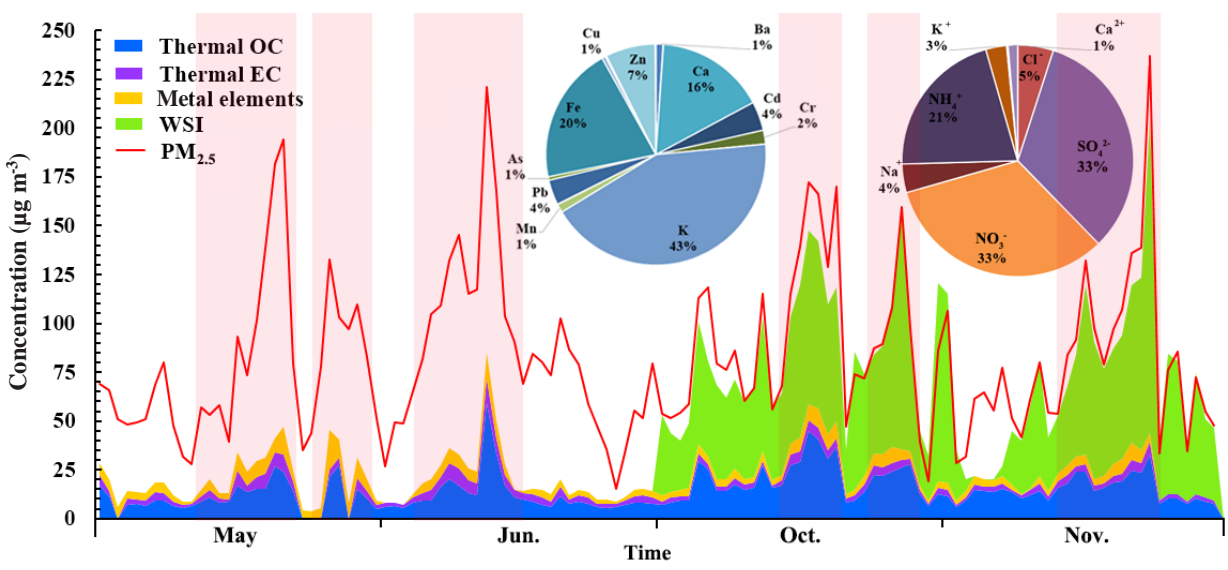

Figure 3. Daily variations of $\mathrm{PM}_{2.5}$ and its components. Pie charts represent the composition of elements and water-soluble ions, respectively. Pink shaded areas represent episodes.

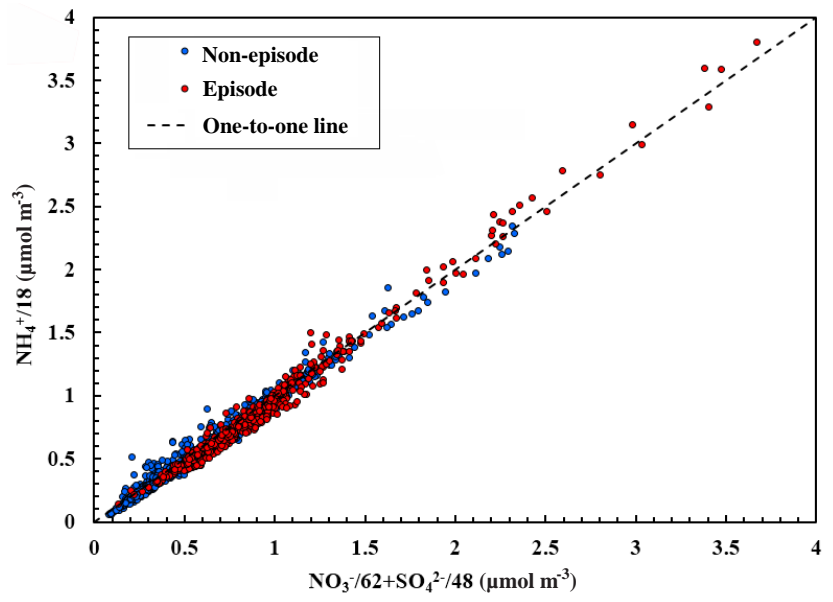

Figure 4. Relative abundance of molar charges of $\mathrm{PM}_{2.5}$ during autumn in Wuhan.

tive radicals in the atmosphere. (A detailed relationship is discussed in Sect. 3.4.3.)

Among the elements, potassium (K; $\left.2060.7 \pm 82.3 \mathrm{ng} \mathrm{m}^{-3}\right)$, iron (Fe; $996.5 \pm 34.3 \mathrm{ng} \mathrm{m}^{-3}$ ), and calcium $\left(\mathrm{Ca} ; 774.1 \pm 39.4 \mathrm{ng} \mathrm{m}^{-3}\right.$ ) were the most abundant species, accounting for $47.0 \% \pm 2.2 \%, 21.4 \% \pm 0.3 \%$, and $15.6 \% \pm 0.3 \%$ of the total analyzed elements, respectively. Correlation analysis indicated that $\mathrm{Fe}$ had good correlation with $\mathrm{Ca}\left(R^{2}=0.66\right.$; Fig. $\mathrm{S} 7$ in the Supplement $)$, whereas weak correlations of $\mathrm{K}$ with $\mathrm{Fe}\left(R^{2}=0.14\right)$ and $\mathrm{Ca}$ $\left(R^{2}=0.09\right)$ were found, suggesting that $\mathrm{Fe}$ and $\mathrm{Ca}$ shared common sources that were different from the sources of $\mathrm{K}$. Because $\mathrm{Fe}$ and $\mathrm{Ca}$ are typical crustal elements, fugitive dust (e.g., dust from traffic, construction and demolition works, yards, and bare soil) was their most likely source. In contrast, apart from emissions from mineral sources, $\mathrm{K}$ is also emitted from biomass burning. As such, $\mathrm{K}$ was believed to be mainly emitted from biomass burning in this study, which is further supported by the moderate correlations of $\mathrm{K}$ with OC $\left(R^{2}=0.52\right)$ and $\mathrm{EC}\left(R^{2}=0.48\right)$ because biomass burning also emits OC and EC (Saarikoski et al., 2007; Echalar et al., 1995).

\subsection{Causes of $\mathrm{PM}_{2.5}$ episodes}

\subsubsection{Meteorological conditions}

The processes of particle formation, dispersion, and deposition are closely related to meteorological conditions. To interpret the possible causes of the $\mathrm{PM}_{2.5}$ episodes, Fig. 7 shows the patterns of wind direction and speed, temperature, relative humidity, and atmospheric pressure in Wuhan during the monitoring period. In general, southeast winds prevailed at the sampling site with a wind speed of approximately $1.0 \mathrm{~m} \mathrm{~s}^{-1}$. The low wind speed indicates the dominance of local air masses. However, due to the high stability and long lifetime of $\mathrm{PM}_{2.5}$, the regional and super-regional impact could not be eliminated. In comparison with those in summer, the wind speed (summer, $1.1 \pm 0.04 \mathrm{~m} \mathrm{~s}^{-1}$; autumn, $0.8 \pm 0.03 \mathrm{~m} \mathrm{~s}^{-1}$ ) and temperature (summer, $25.6 \pm 0.2 \mathrm{~m} \mathrm{~s}^{-1}$; autumn, $17.5 \pm 0.3 \mathrm{~m} \mathrm{~s}^{-1}$ ) were significantly $(p<0.05)$ lower in autumn, whereas the atmospheric pressure (summer, $1006.9<0.2 \mathrm{hPa}$; autumn, $1020.9 \pm 0.2 \mathrm{hPa}$ ) was much higher. During the episodes, the wind speed was generally lower than during non-episodes, with the exception of episode 5. This might be one cause for the episodes, but it does not fully explain the great enhancements of $\mathrm{PM}_{2.5}$, because the wind speeds were very low and the differences between the episodes and non-episodes were minor. The atmospheric pressure was not very high during episodes 1 through 5 , suggesting that the synoptic system was not responsible for the occurrence of these $\mathrm{PM}_{2.5}$ episodes. However, the atmospheric pressure was remarkably higher $(p<0.05)$ in episode $6(1024 \pm 1 \mathrm{hPa})$ than in nonepisode $2(1021 \pm 0.3 \mathrm{hPa})$, which might have suppressed the 

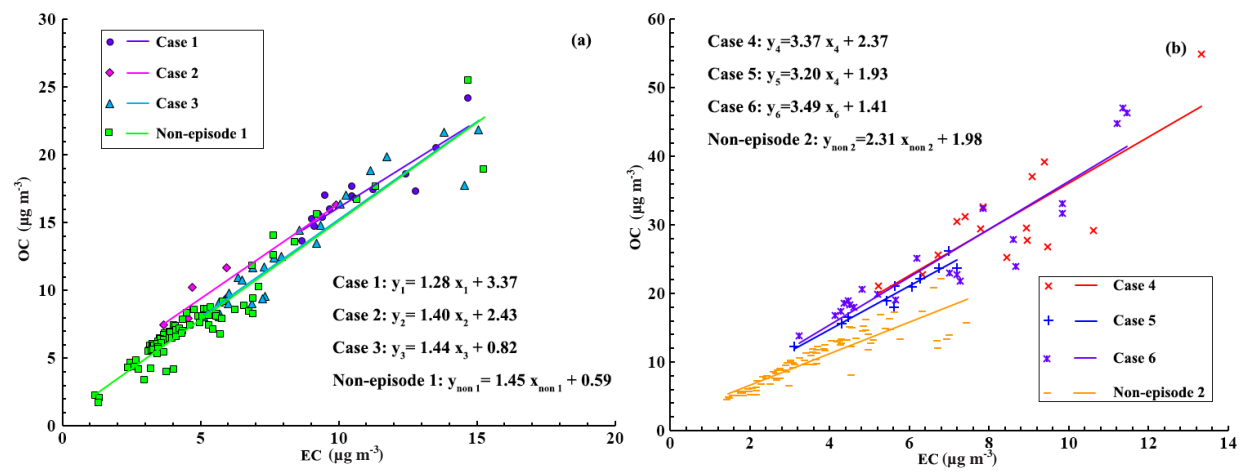

Figure 5. Regression between OC and EC with the $10 \%$ lowest OC / EC ratios during (a) summer and (b) autumn in Wuhan.

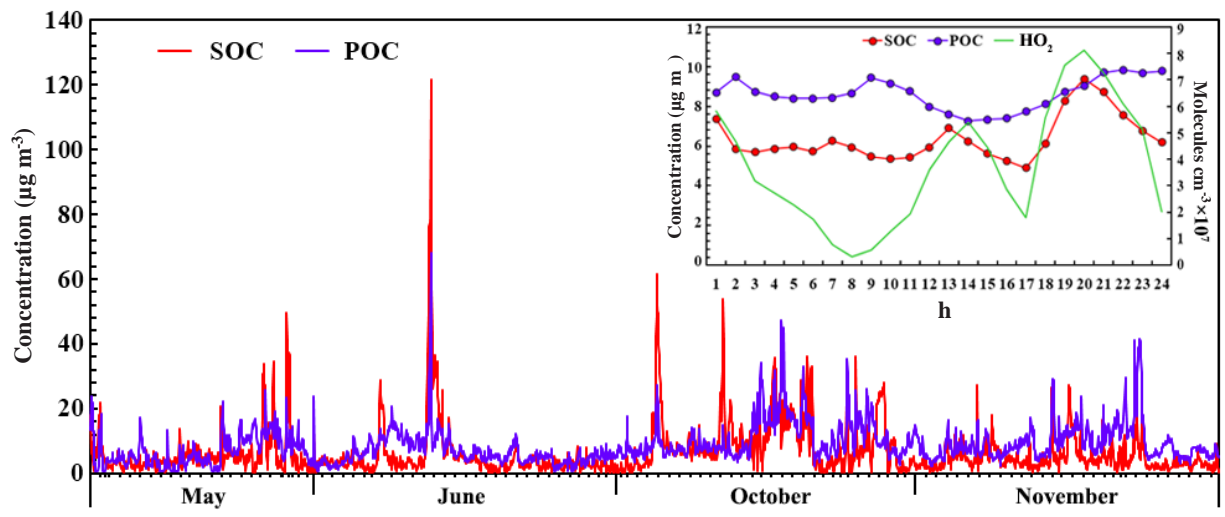

Figure 6. Hourly concentrations of SOC and POC. Insert graph presents average diurnal variations of $\mathrm{SOC}, \mathrm{POC}$, and $\mathrm{HO}_{2}$.

diffusion of $\mathrm{PM}_{2.5}$ and the gaseous precursors. In addition, the temperature was lower (episode $6,14.0^{\circ} \mathrm{C} \pm 0.4^{\circ} \mathrm{C}$; nonepisode $2,17.2{ }^{\circ} \mathrm{C} \pm 0.3{ }^{\circ} \mathrm{C} ; p<0.05$ ), which favors the gasto-particle partitioning of semivolatile and non-thermal stabilized species. As a consequence, these effects might have elevated the $\mathrm{PM}_{2.5}$ concentrations in episode 6, which is discussed further in Sect. 3.4.2.

\subsubsection{Chemical signatures}

Table 3 summarizes the mass concentrations and percentages of the main components in $\mathrm{PM}_{2.5}$. The mass concentrations of $\mathrm{PM}_{2.5}$ components significantly increased from non-episode days to episode days $(p<0.05)$. In contrast, the percentages of the chemical components in $\mathrm{PM}_{2.5}$ varied by species. In summer, the fractions of EC and $\mathrm{K}$ in $\mathrm{PM}_{2.5}$ experienced significant increases from nonepisode $1(\mathrm{EC}, 4.8 \% \pm 0.2 \% ; \mathrm{K}, 2.0 \% \pm 0.1 \%$ ) to episode 1 (EC, $5.7 \% \pm 0.5 \% ; \mathrm{K}, 4.4 \% \pm 0.3 \%$ ) and episode 3 (EC, $5.3 \% \pm 0.2 \% ; \mathrm{K}, 3.0 \% \pm 0.2 \%)$. Because $\mathrm{EC}$ is the tracer of incomplete combustion (Chow et al., 1996) and $\mathrm{K}$ is the indicator of biomass burning (Saarikoski et al., 2007; Echalar et al., 1995), the higher percentages of EC and $\mathrm{K}$ in episodes 1 and 3 imply the outstanding contribu- tion of biomass burning. In contrast, the fraction of OC in $\mathrm{PM}_{2.5}$ remained stable on both episode and non-episode days $(p>0.05)$, possibly because the high temperatures in summer hindered the gas-to-particle partitioning of semivolatile organics (Takekawa et al., 2003). Furthermore, the percentages of $\mathrm{Ca}(2.9 \% \pm 0.4 \%)$ and $\mathrm{Fe}(2.7 \% \pm 0.3 \%)$ significantly increased during episode $2(p<0.05)$ compared to those in non-episode $1(\mathrm{Ca}, 1.1 \% \pm 0.1 \%$; Fe, $1.5 \% \pm 0.1 \%$ ), which shows that fugitive dust made a considerable contribution to $\mathrm{PM}_{2.5}$ in episode 2. In addition, biomass burning might also have contributed to $\mathrm{PM}_{2.5}$, in view of the increase in the percentage of $\mathrm{K}$ (non-episode 1 , $2.0 \% \pm 0.1 \%$; episode $2,3.2 \% \pm 0.2 \%$ ).

In autumn, the percentage of K significantly $(p<0.05)$ increased during episode $4(3.1 \% \pm 0.1 \%$ vs. $2.1 \% \pm 0.1 \%$ in non-episode 2$)$, as did that of OC $(27.3 \% \pm 0.7 \%$ vs. $20.9 \% \pm 0.8 \%$ in non-episode 2 ), suggesting the dominant role of biomass burning in episode 4. Furthermore, the fractions of OC in episode $5(23.8 \% \pm 1.5 \%)$ and $\mathrm{NO}_{3}^{-}$in episode $6(26.1 \% \pm 1.0 \%)$ were obviously higher than those in non-episode $2\left(\mathrm{OC}, 20.9 \% \pm 0.8 \% ; \mathrm{NO}_{3}^{-}\right.$, $19.8 \% \pm 0.9 \%$ ). Due to the complexity of the sources of OC and $\mathrm{NO}_{3}^{-}$, the causes of episodes 5 and 6 are further explored in the following sections. 


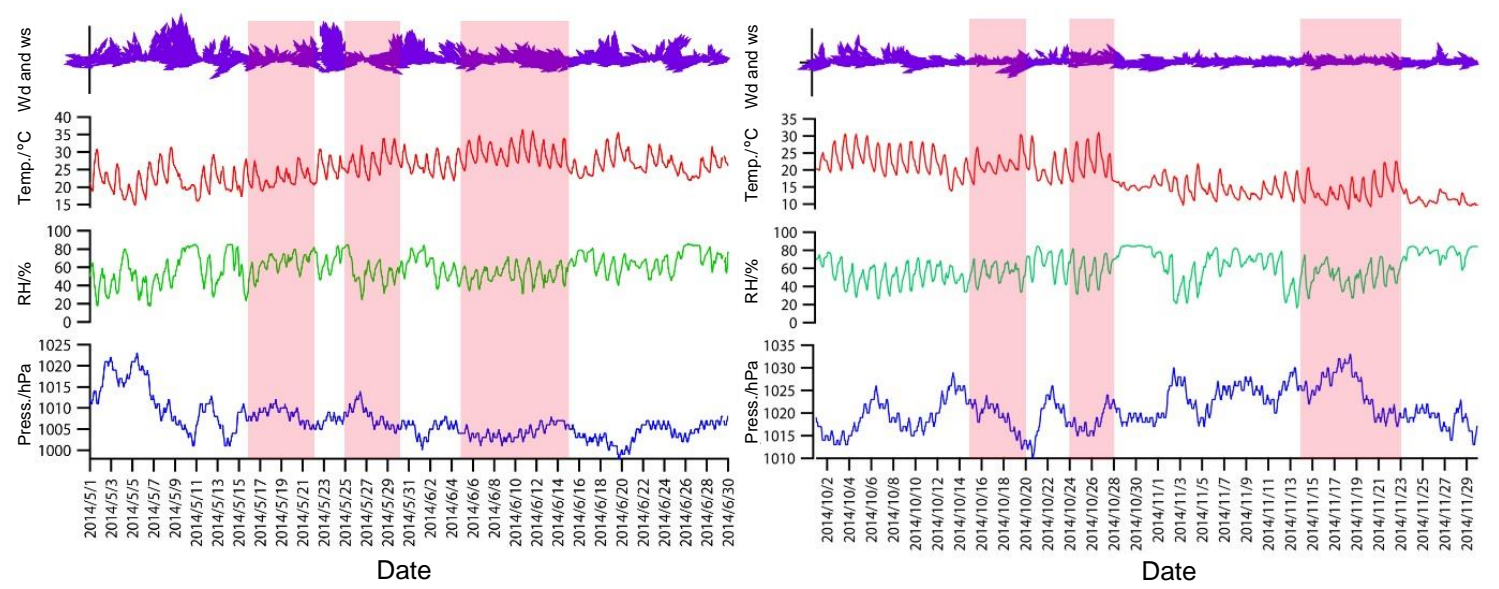

Figure 7. Meteorological patterns in Wuhan during the monitoring period. Pink shaded areas represent $\mathrm{PM}_{2.5}$ episodes.

In summary, episodes 1,3 , and 4 were greatly affected by biomass burning. This finding was further confirmed by the significant increases in the gaseous tracers of biomass burning such as ethyne $\left(\mathrm{C}_{2} \mathrm{H}_{2}\right)$ and methyl chloride $\left(\mathrm{CH}_{3} \mathrm{Cl}\right)$ (Guo et al., 2011b; Simoneit, 2002) during these episodes $(p<0.05$; see Fig. S8 in the Supplement).

\subsubsection{Source apportionment}

To clarify the sources of $\mathrm{PM}_{2.5}$ and quantify their contributions, the hourly data on $\mathrm{PM}_{2.5}$ components were applied to PMF for source apportionment. Five and six sources were resolved for summer and autumn, respectively, as shown in Figs. 8 and 9. The source of SIA was missing in summer, due to the lack of WSI data. For other sources, the profile of each corresponding source was similar in summer and autumn. Factor 1 had high loadings of crustal elements (i.e., $\mathrm{Ba}, \mathrm{Ca}, \mathrm{Mn}$, and $\mathrm{Fe}$ ), indicating the source of fugitive dust. Factor 2 was likely associated with oil refinery and usage, in view of the high percentages of $\mathrm{V}$ and $\mathrm{Ni}$, which often originate from the combustion of heavy oil (Barwise, 1990; Nriagu and Pacyna, 1988). Factor 3 was distinguished by the high loadings of OC, EC, and $\mathrm{K}$, indicating the biomass burning source (Zhang et al., 2013; Friedli et al., 2003). Factor 4 seemed to represent vehicle emissions, due to the dominance of $\mathrm{Pb}, \mathrm{As}, \mathrm{Cu}$, and $\mathrm{Se} . \mathrm{Cu}$ has been identified as one of the most abundant metals in both brake linings and the brake wear particles with the concentration of up to $210 \mathrm{mg} \mathrm{g}^{-1}$ in brake wear dust (Grigoratos and Martini, 2015). Although lead-containing gasoline has been forbidden in China since 2000 , high levels of $\mathrm{Pb}$ are often reported in traffic sources (Yang et al., 2013; Song et al., 2012), which might be due to the use of $\mathrm{Pb}$-containing materials in car components, such as lead wheel weights, solder in electronics, and lead-acid batteries (Song et al., 2012). Both biomass burning and vehicular emissions are important sources of EC. The much lower EC apportioned to vehicular emissions in this study is ex- plained in Sect. 1 of the Supplement. OC and Hg dominated in factor 5, and $\mathrm{Cl}^{-}$also showed high loading in this factor in the autumn profile. It is well documented that $\mathrm{Hg}$ and $\mathrm{Cl}^{-}$ are largely emitted from coal combustion (Wang et al., 2010; Ye et al., 2003). Hence, this factor was assigned as coal combustion. Finally, a source of SIA with high loadings of $\mathrm{NO}_{3}^{-}$, $\mathrm{SO}_{4}^{2-}$, and $\mathrm{NH}_{4}^{+}$was resolved in autumn.

Figures S9 and S10 in the Supplement show the dayto-day variations of the source contributions in summer and autumn, respectively. Overall, biomass burning was the largest contributor $(45.0 \% \pm 0.03 \%)$ to $\mathrm{PM}_{2.5}$ in summer. However, the contribution of biomass burning in autumn $(23.7 \% \pm 0.5 \%)$ was lower than that of SIA $(38.6 \% \pm 0.7 \%)$. Bearing in mind the uncertainties caused by the lack of WSIs, the greater contribution of biomass burning in summer might be associated with the lower WSIs. For example, $\mathrm{NO}_{3}^{-}$was expected to be much lower in summer due to its thermal decomposition at high temperatures. Table 4 summarizes the source contributions during episodes and non-episodes. Noticeably, the contributions of biomass burning were significantly higher $(p<0.05)$ in episode $1\left(59.2 \pm 6.3 \mu \mathrm{g} \mathrm{m}^{-3} ; 46.6 \% \pm 3.0 \%\right)$, episode $3\left(64.9 \pm 3.3 \mu \mathrm{g} \mathrm{m}^{-3} ; 50.8 \% \pm 1.2 \%\right)$, and episode $4\left(48.7 \pm 2.9 \mu \mathrm{g} \mathrm{m}^{-3} ; 44.8 \% \pm 2.6 \%\right)$ than those in the corresponding non-episodes, confirming that biomass burning was the main cause of these $\mathrm{PM}_{2.5}$ episodes. In addition, vehicle emissions made a greater contribution to episode $4\left(14.9 \pm 1.2 \mu \mathrm{g} \mathrm{m}^{-3} ; 13.7 \% \pm 1.1 \%\right)$ than to non-episode 2 . In contrast, the contribution of fugitive dust $\left(6.5 \pm 1.3 \mu \mathrm{g} \mathrm{m}^{-3} ; 5.6 \% \pm 1.0 \%\right)$ in episode 2 was remarkably $(p<0.05)$ higher than in non-episode 1 $\left(1.1 \pm 0.1 \mu \mathrm{g} \mathrm{m}^{-3} ; 1.8 \% \pm 0.2 \%\right)$. This finding was consistent with the inference that episode 2 was attributable to fugitive dust according to the low $\mathrm{PM}_{2.5} / \mathrm{PM}_{10}$ ratio $(45.9 \% \pm 2.5 \%)$ and high levels of crustal elements $(\mathrm{Ca}$, $2.9 \% \pm 0.4 \%$; Fe, $2.7 \% \pm 0.3 \%$ ) in this episode. In addition, vehicle emissions and SIA both experienced significant 
Table 3. Concentrations $\left(\mu \mathrm{g} \mathrm{m}^{-3}\right.$ ) and percentages (in parentheses) of the main components of $\mathrm{PM}_{2.5}$ during non-episodes and episodes. Bold font demonstrates significant increase in percentage of $\mathrm{PM}_{2.5}$ components during episodes compared to non-episodes.

\begin{tabular}{|c|c|c|c|c|c|c|c|c|}
\hline & \multicolumn{4}{|c|}{ Summer } & \multicolumn{4}{|c|}{ Autumn } \\
\hline & Episode 1 & Episode 2 & Episode 3 & Non-episode 1 & Episode 4 & Episode 5 & Episode 6 & Non-episode 2 \\
\hline $\mathrm{OC}$ & $\begin{array}{r}18.5 \pm 1.3 \\
(15.1 \% \pm 0.8 \%)\end{array}$ & $\begin{array}{r}16.3 \pm 3.3 \\
(14.0 \% \pm 1.9 \%)\end{array}$ & $\begin{array}{r}19.8 \pm 2.5 \\
(14.5 \% \pm 1.0 \%)\end{array}$ & $\begin{array}{r}7.9 \pm 0.3 \\
(15.4 \% \pm 0.7 \%)\end{array}$ & $\begin{array}{r}\mathbf{3 5 . 1} \pm \mathbf{1 . 7} \\
(\mathbf{2 7 . 3} \% \pm \mathbf{0 . 7} \%)\end{array}$ & $\begin{array}{r}24.9 \pm 1.9 \\
(23.8 \% \pm 1.5 \%)\end{array}$ & $\begin{array}{r}22.7 \pm 1.5 \\
(21.4 \% \pm 0.8 \%)\end{array}$ & $\begin{array}{r}14.6 \pm 1.0 \\
(20.9 \% \pm 0.8 \%)\end{array}$ \\
\hline $\mathrm{EC}$ & $\begin{array}{r}\mathbf{6 . 8} \pm \mathbf{0 . 5} \\
(5.7 \% \pm \mathbf{0 . 5} \%)\end{array}$ & $\begin{array}{r}4.3 \pm 0.6 \\
(4.1 \% \pm 0.5 \%)\end{array}$ & $\begin{array}{r}\text { 6.6 } \pm \mathbf{0 . 5} \\
(5.3 \% \pm \mathbf{0 . 2} \%)\end{array}$ & $\begin{array}{r}2.8 \pm 0.1 \\
(4.8 \% \pm 0.2 \%)\end{array}$ & $\begin{array}{r}5.4 \pm 0.4 \\
(4.2 \% \pm 0.3 \%)\end{array}$ & $\begin{array}{r}4.2 \pm 0.4 \\
(4.1 \% \pm 0.4 \%)\end{array}$ & $\begin{array}{r}4.2 \pm 0.4 \\
(3.9 \% \pm 0.2 \%)\end{array}$ & $\begin{array}{r}2.7 \pm 0.2 \\
(4.0 \% \pm 0.2 \%)\end{array}$ \\
\hline $\mathrm{SO}_{4}^{2-}$ & NA & NA & NA & NA & $\begin{array}{r}28.3 \pm 0.9 \\
(22.8 \% \pm 0.9 \%)\end{array}$ & $\begin{array}{r}25.9 \pm 2.4 \\
(23.7 \% \pm 1.1 \%)\end{array}$ & $\begin{array}{r}21.3 \pm 2.0 \\
(19.2 \% \pm 0.6 \%)\end{array}$ & $\begin{array}{r}18.8 \pm 0.9 \\
(26.9 \% \pm 0.9 \%)\end{array}$ \\
\hline $\mathrm{NO}_{3}^{-}$ & NA & NA & NA & NA & $\begin{array}{r}23.7 \pm 1.9 \\
(17.8 \% \pm 0.9 \%)\end{array}$ & $\begin{array}{r}24.7 \pm 2.9 \\
(21.4 \% \pm 1.1 \%)\end{array}$ & $\begin{array}{r}\mathbf{3 0 . 8} \pm \mathbf{3 . 6} \\
(26.1 \% \pm \mathbf{1 . 0} \%)\end{array}$ & $\begin{array}{r}15.8 \pm 1.3 \\
(19.8 \% \pm 0.9 \%)\end{array}$ \\
\hline $\mathrm{NH}_{4}^{+}$ & NA & NA & NA & NA & $\begin{array}{r}16.5 \pm 0.8 \\
(12.9 \% \pm 0.2 \%)\end{array}$ & $\begin{array}{r}15.6 \pm 1.8 \\
(13.7 \% \pm 0.6 \%)\end{array}$ & $\begin{array}{r}16.8 \pm 1.8 \\
(14.5 \% \pm 0.3 \%)\end{array}$ & $\begin{array}{r}11.0 \pm 0.7 \\
(14.9 \% \pm 0.3 \%)\end{array}$ \\
\hline K & $\begin{array}{r}5.3 \pm 0.6 \\
(4.4 \% \pm 0.3 \%)\end{array}$ & $\begin{array}{r}3.4 \pm 0.4 \\
(3.2 \% \pm 0.2 \%)\end{array}$ & $\begin{array}{r}3.8 \pm 0.5 \\
(3.0 \% \pm 0.2 \%)\end{array}$ & $\begin{array}{r}1.1 \pm 0.1 \\
(2.0 \% \pm 0.1 \%)\end{array}$ & $\begin{array}{r}4.0 \pm \mathbf{0 . 2} \\
(3.1 \% \pm \mathbf{0 . 1} \%)\end{array}$ & $\begin{array}{r}2.3 \pm 0.2 \\
(2.2 \% \pm 0.1 \%)\end{array}$ & $\begin{array}{r}2.4 \pm 0.2 \\
(2.2 \% \pm 0.1 \%)\end{array}$ & $\begin{array}{r}1.4 \pm 0.1 \\
(2.1 \% \pm 0.1 \%)\end{array}$ \\
\hline $\mathrm{Ca}$ & $\begin{array}{r}1.2 \pm 0.4 \\
(1.1 \% \pm 0.1 \%)\end{array}$ & $\begin{array}{r}3.2 \pm 0.4 \\
(2.9 \% \pm 0.4 \%)\end{array}$ & $\begin{array}{r}0.9 \pm 0.3 \\
(0.8 \% \pm 0.1 \%)\end{array}$ & $\begin{array}{r}0.6 \pm 0.04 \\
(1.1 \% \pm 0.1 \%)\end{array}$ & $\begin{array}{r}1.1 \pm 0.1 \\
(0.9 \% \pm 0.1 \%)\end{array}$ & $\begin{array}{r}0.8 \pm 0.2 \\
(0.8 \% \pm 0.2 \%)\end{array}$ & $\begin{array}{r}0.8 \pm 0.1 \\
(0.8 \% \pm 0.1 \%)\end{array}$ & $\begin{array}{r}0.3 \pm 0.04 \\
(0.5 \% \pm 0.1 \%)\end{array}$ \\
\hline $\mathrm{Fe}$ & $\begin{array}{r}1.4 \pm 0.1 \\
(1.3 \% \pm 0.1 \%)\end{array}$ & $\begin{array}{r}2.8 \pm \mathbf{0 . 3} \\
(2.7 \% \pm 0.3 \%)\end{array}$ & $\begin{array}{r}1.1 \pm 0.1 \\
(1.0 \% \pm 0.1 \%)\end{array}$ & $\begin{array}{r}0.8 \pm 0.05 \\
(1.5 \% \pm 0.1 \%)\end{array}$ & $\begin{array}{r}1.5 \pm 0.1 \\
(1.2 \% \pm 0.2 \%)\end{array}$ & $\begin{array}{r}1.2 \pm 0.2 \\
(1.2 \% \pm 0.2 \%)\end{array}$ & $\begin{array}{r}1.2 \pm 0.1 \\
(1.1 \% \pm 0.1 \%)\end{array}$ & $\begin{array}{r}0.6 \pm 0.04 \\
(0.9 \% \pm 0.1 \%)\end{array}$ \\
\hline
\end{tabular}

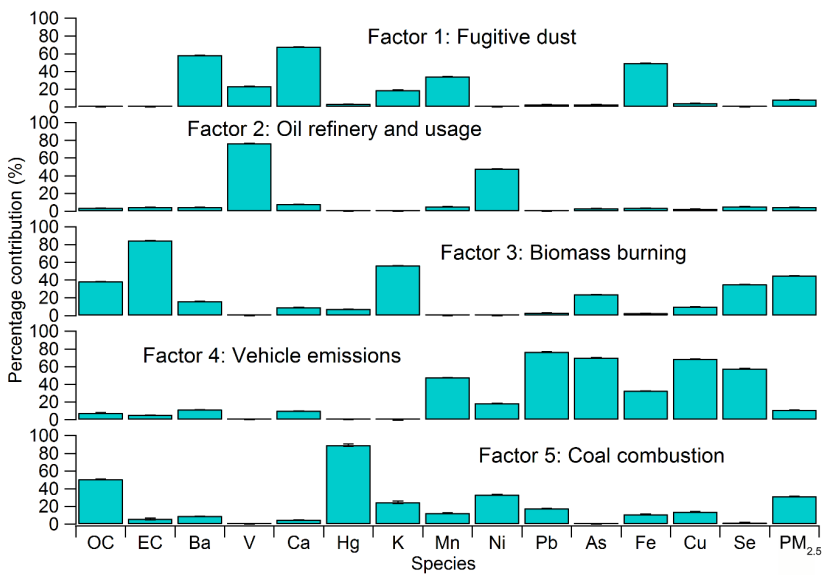

Figure 8. Profiles of $\mathrm{PM}_{2.5}$ sources in summer. Error bars represent $95 \%$ CI estimated by bootstrap method in PMF.

increases in episodes 5 and $6(p<0.05)$. In fact, the increase of OC in episode 5 (see Table 3 ) was mainly caused by vehicle emissions and coal combustion (Table S3 in the Supplement). For episode 6 , in addition to the increase in OC, SIA was also an important contributor, particularly for $\mathrm{NO}_{3}^{-}$, which increased from $9.9 \pm 1.2 \mu \mathrm{g} \mathrm{m}^{-3}$ in non-episode 2 to $21.4 \pm 3.3 \mu \mathrm{g} \mathrm{m}^{-3}$ in episode 6 (Table S3). In addition, we noted that the contribution of coal combustion was much lower in non-episode 2 than that in non-episode1 $(p<0.05)$. The explanation is provided in Sect. 2 of the Supplement.

\subsubsection{Open fires and air mass trajectories}

To further confirm the biomass burning activities during the $\mathrm{PM}_{2.5}$ episodes, the wildfire distribution (NASA, 2014) and $72 \mathrm{~h}$ backward air mass trajectories (simulated by Hysplit v4.9 model) are plotted in Fig. 10. Because the concentra-

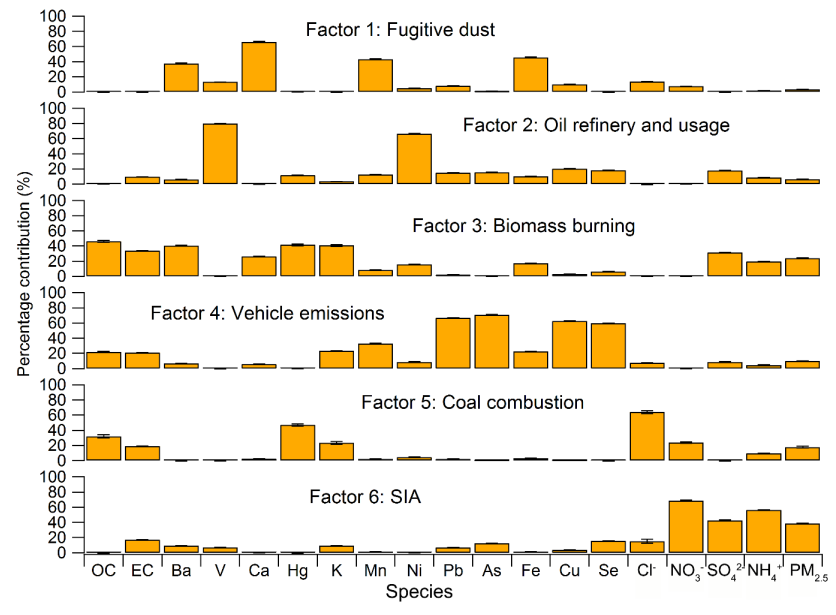

Figure 9. Profiles of $\mathrm{PM}_{2.5}$ sources in autumn. Error bars represent $95 \%$ CI estimated by bootstrap method in PMF.

tions, compositions and source contributions of $\mathrm{PM}_{2.5}$ were averaged over the entire period of each episode, the wildfire distribution and backward trajectories were also averaged for the entire period of each episode. Consistent with the great contributions to $\mathrm{PM}_{2.5}$ of biomass burning, the air masses arriving in Wuhan had passed over the areas where intensive open fires were detected in episodes 1, 3, and 4. In episode 2, wildfires were widespread in northeast China. However, the air mass trajectories were mainly from the south and northwest and evaded the burning areas, which might explain why biomass burning was not a predominant factor in episode 2 . The sparse wildfires in episodes 5 and 6 coincided with the source apportionment result that biomass burning did not significantly elevate the concentration of $\mathrm{PM}_{2.5}$. 
Table 4. Mass concentration $\left(\mu \mathrm{g} \mathrm{m}^{-3}\right.$ ) and percentage contribution (in parentheses) of sources to sum of resolved species in $\mathrm{PM}_{2.5}$. Bold font represents a significant increase in percentage contribution in episodes compared to non-episodes.

\begin{tabular}{|c|c|c|c|c|c|c|}
\hline & Fugitive dust & Oil refinery and usage & Biomass burning & Vehicle emissions & Coal combustion & SIA \\
\hline \multirow[t]{2}{*}{ Episode 1} & $10.0 \pm 1.3$ & $4.0 \pm 1.2$ & $59.2 \pm 6.3$ & $12.2 \pm 1.8$ & $36.0 \pm 2.7$ & - \\
\hline & $(8.7 \% \pm 1$ & $(2.8 \% \pm 0.7 \%)$ & $(46.6 \% \pm 3.0 \%)$ & $(9.6 \% \pm 1.2 \%)$ & $(32.2 \% \pm 2$. & \\
\hline \multirow[t]{2}{*}{ Episode 2} & $29.5 \pm 6.1$ & $8.2 \pm 2.6$ & $37.1 \pm 5.8$ & $10.8 \pm 3.1$ & $20.9 \pm 4.7$ & - \\
\hline & $(27.5 \% \pm 5$ & $(6.7 \% \pm 1.7$ & $(35.3 \% \pm 4.8 \%)$ & $(11.9 \% \pm 3.2 \%)$ & $(18.7 \% \pm 3.1 \%)$ & \\
\hline \multirow[t]{2}{*}{ Episode 3} & $6.4 \pm$ & $4.9 \pm 1.0$ & $64.9 \pm 3.3$ & $8.8 \pm 0.9$ & $41.6 \pm 3.3$ & - \\
\hline & $(5.3 \% \pm 0.4 \%)$ & $(3.9 \% \pm 0.7 \%)$ & $(50.8 \% \pm 1.2 \%)$ & $(7.9 \% \pm 0.9 \%)$ & $(32.1 \% \pm 1.5 \%)$ & \\
\hline \multirow[t]{2}{*}{ Non-episode 1} & $4.8 \pm 0.6$ & $2.9 \pm 0.4$ & $22.2 \pm 1.6$ & $9.3 \pm 0.6$ & $19.5 \pm 1.0$ & - \\
\hline & $(8.7 \% \pm 1.0 \%)$ & $(5.0 \% \pm 0.7 \%)$ & $(35.2 \% \pm 1.9 \%)$ & $(16.3 \% \pm 1.0 \%)$ & $(35.9 \% \pm 1.7 \%)$ & \\
\hline \multirow[t]{2}{*}{ Episode 4} & $3.3=$ & $7.2 \pm 0.6$ & $48.7 \pm 2.9$ & $14.9 \pm 1.2$ & $13.8 \pm 1.7$ & $23.3 \pm 3.3$ \\
\hline & $(3.0 \% \pm 0.2 \%)$ & $(7.0 \% \pm 0.8 \%)$ & $(44.8 \% \pm 2.6 \%)$ & $(13.7 \% \pm 1.1 \%)$ & $(11.9 \% \pm 1.3 \%)$ & $(19.6 \% \pm 2.6 \%)$ \\
\hline \multirow[t]{2}{*}{ Episode 5} & $2.3 \pm 0.5$ & $5.3 \pm 0.6$ & $21.1 \pm 2.8$ & $12.2 \pm 1.9$ & $14.8 \pm 2.0$ & $39.9 \pm 6.4$ \\
\hline & $(2.7 \% \pm 0.5 \%)$ & $(6.6 \% \pm 0.8 \%)$ & $(22.1 \% \pm 2.3 \%)$ & $(13.85 \pm 2.1 \%)$ & $(17.5 \% \pm 2.7 \%)$ & $(37.2 \% \pm \mathbf{3 . 0} \%)$ \\
\hline \multirow[t]{2}{*}{ Episode 6} & $2.6 \pm 0.3$ & $4.7 \pm 0.6$ & $18.4 \pm 2.4$ & $14.2 \pm 1.3$ & $17.7 \pm 2.5$ & $44.6 \pm 6.8$ \\
\hline & $(3.0 \% \pm 0.3 \%)$ & $(4.7 \% \pm 0.4 \%)$ & $(21.2 \% \pm 2.5 \%)$ & $(16.1 \% \pm 1.3 \%)$ & $(16.3 \% \pm 1.7 \%)$ & $(38.7 \% \pm 2.2 \%)$ \\
\hline \multirow[t]{2}{*}{ Non-episode 2} & $0.9 \pm 0.1$ & $4.7 \pm 0.3$ & $22.2 \pm 1.6$ & $4.2 \pm 0.4$ & $9.8 \pm 0.8$ & $20.5 \pm 2.5$ \\
\hline & $(1.6 \% \pm 0.2 \%)$ & $(8.6 \% \pm 0.6 \%)$ & $(39.3 \% \pm 2.5 \%)$ & $(7.4 \% \pm 0.7 \%)$ & $(18.1 \% \pm 1.8 \%)$ & $(25.0 \% \pm 2.3 \%)$ \\
\hline
\end{tabular}

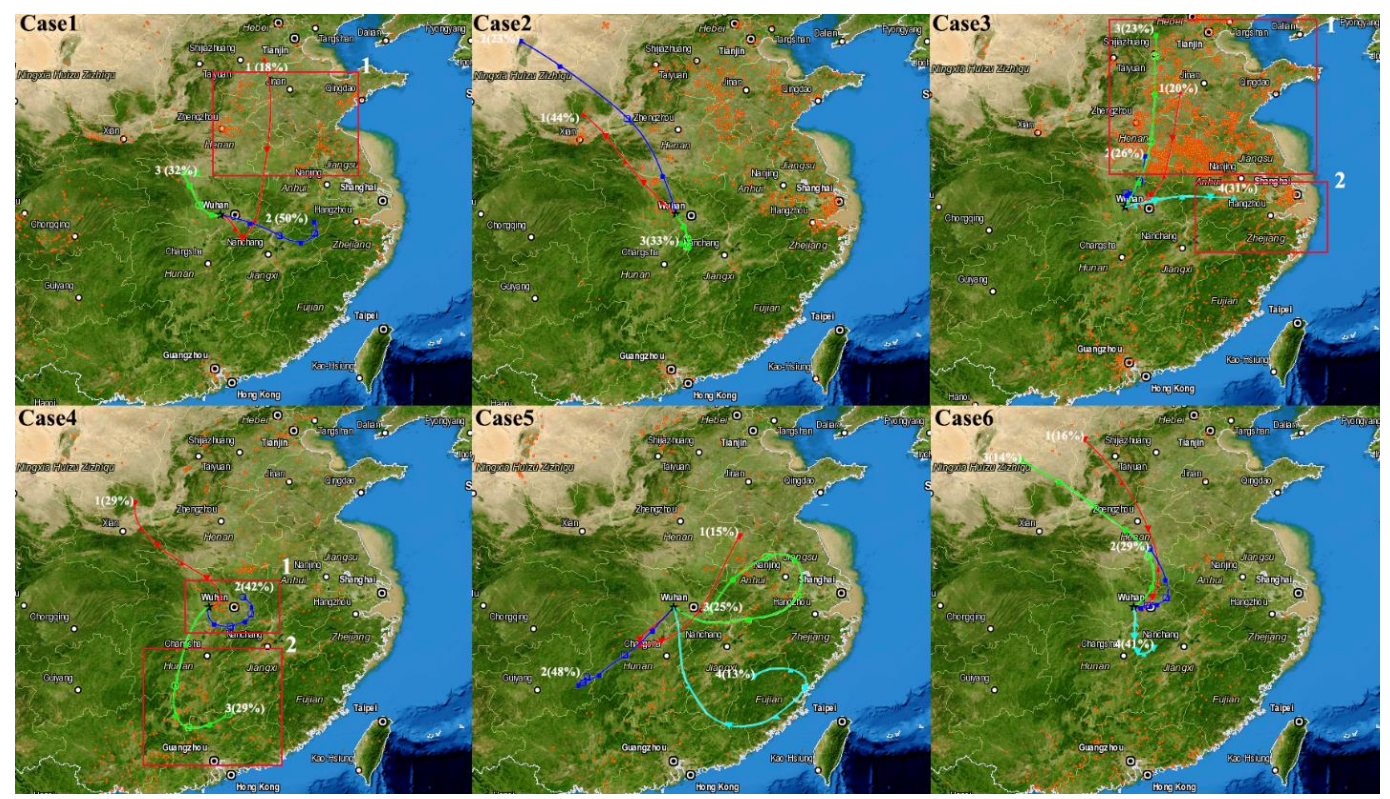

Figure 10. Wildfire distribution and $72 \mathrm{~h}$ backward air mass trajectories. Red squares demonstrate potential areas where biomass burning aggravated particulate pollution in Wuhan.

\subsection{Formation mechanisms}

\subsubsection{Model validation}

In this study, the PBM-MCM model was used to help investigate the formation mechanisms of $\mathrm{NO}_{3}^{-}$and SOC. Before application, the model was validated via $\mathrm{O}_{3}$ simulation. Figure S11 compares the daily averages and diurnal variations of $\mathrm{O}_{3}$ between the simulation and the observations. It was found that the model simulated $\mathrm{O}_{3}$ variation well in both daily and diurnal patterns. However, it generally overestimated the
$\mathrm{O}_{3}$ levels in November. The meteorological parameters indicated that the frequency of foggy days was extremely high $(36.7 \%)$ in November, possibly resulting in a weakening of solar radiation and consequently of photochemical reactivity. To quantitatively evaluate the performance of the model, the index of agreement (IOA) was calculated using Eq. (9).

$$
\mathrm{IOA}=1-\frac{\sum_{i=1}^{n}\left(O_{i}-S_{i}\right)^{2}}{\sum_{i=1}^{n}\left(\left|O_{i}-\bar{O}\right|+\left|S_{i}-\bar{O}\right|\right)^{2}},
$$


where $\bar{O}$ is the average of $n$ samples and $O_{i}$ and $S_{i}$ represent the observed and simulated values, respectively. Within the interval of $[0,1]$, higher IOA values indicated better agreement between the simulation and observation.

By calculation, the IOA reached 0.86, indicating excellent performance of the model in the $\mathrm{O}_{3}$ simulation. Because $\mathrm{O}_{3}$ production is closely associated with oxidative radicals, intermediates, and products, the robust $\mathrm{O}_{3}$ simulation gave us full confidence to accept the simulated $\mathrm{N}_{2} \mathrm{O}_{5}, \mathrm{HO}_{2}$, and SVOCs.

\subsection{2 $\mathrm{NO}_{3}^{-}$formation}

The composition analysis indicated that the proportion of $\mathrm{NO}_{3}^{-}$increased remarkably during episode 6 . To interpret this phenomenon, the formation mechanisms of $\mathrm{NO}_{3}^{-}$were investigated. Figure 11 shows the hourly variations of the calculated and observed $\mathrm{NO}_{3}^{-}$and the contribution of Reaction (R3) (i.e., $\mathrm{N}_{2} \mathrm{O}_{5}+\mathrm{H}_{2} \mathrm{O} \rightarrow 2 \mathrm{HNO}_{3}$ ), among which $\mathrm{NO}_{3}^{-}$cal1, $\mathrm{NO}_{3}^{-}$cal2, and $\mathrm{NO}_{3}^{-}$obs referred to homogeneous formation (Reactions R1 and R2), total formation (Reactions $\mathrm{R} 1, \mathrm{R} 2$, and $\mathrm{R} 3$ ), and field measurement of $\mathrm{NO}_{3}^{-}$, respectively. Although the particle-bound $\mathrm{NO}_{3}^{-}$was influenced by many factors (i.e., formation, deposition, and dispersion), the calculations generally well reproduced the measured $\mathrm{NO}_{3}^{-}$in episode 6, with a high correlation coefficient $\left(R^{2}=0.63\right)$ and an IOA of 0.78. However, on 23 November 2014, the observed $\mathrm{NO}_{3}^{-}$decreased rapidly from 09:00, which was not captured by the calculations. This discrepancy was likely caused by the weather conditions on that day, because (1) the average wind speed increased from $1.7 \mathrm{~m} \mathrm{~s}^{-1}$ before 09:00 to $2.7 \mathrm{~m} \mathrm{~s}^{-1}$ after 09:00 and even reached $4.0 \mathrm{~m} \mathrm{~s}^{-1}$ at 14:00; and (2) moderate rain began at 12:00 and continued until 23:00, with total precipitation of $24 \mathrm{~mm}$. Indeed, this was the beginning of a 7-day rainy period, which ended episode 6 with a sharp decrease of the $\mathrm{PM}_{2.5}$ concentration (approximately $175 \mu \mathrm{g} \mathrm{m}^{-3}$; see Fig. 2).

Because the values of $\mathrm{NO}_{3}^{-}$cal1 were very close to those of $\mathrm{NO}_{3}^{-}$cal2, the variation of $\mathrm{NO}_{3}^{-}$in episode 6 could be well explained by the homogeneous formation (Reactions $\mathrm{R} 1$ and R2), whereas the heterogeneous reaction of $\mathrm{N}_{2} \mathrm{O}_{5}$ on aerosol surfaces (Reaction R3) made only a minor contribution to the total $\mathrm{NO}_{3}^{-}$(i.e., nearly nil from 00:00 to $17: 00$ and $3.7 \% \pm 0.6 \%$ from 18:00 to $23: 00$ ). Because the homogeneous formation of $\mathrm{NO}_{3}^{-}$was closely related to the concentrations of $\mathrm{HNO}_{3(\mathrm{~g})}$ and $\mathrm{NH}_{3(\mathrm{~g})}$ and the temperature (see Reactions R1 and R2), Table 5 compares the temperature, $\mathrm{HNO}_{3(\mathrm{~g})}, \mathrm{NH}_{3(\mathrm{~g})}, \mathrm{NO}, \mathrm{NO}_{2}, \mathrm{O}_{3}$, and the simulated $\mathrm{OH}$ and $\mathrm{HO}_{2}$ (a measure of oxidative capacity; Cheng et al., 2010) between episode 6 and non-episode 2. It was found that the levels of $\mathrm{HNO}_{3(\mathrm{~g})}(0.65 \pm 0.01 \mathrm{ppbv})$ and $\mathrm{NH}_{3(\mathrm{~g})}(13.48 \pm 0.72 \mathrm{ppbv})$ in episode 6 were significantly higher than those during the non-episode $2(0.47 \pm 0.03$ and $9.54 \pm 0.37 \mathrm{ppbv}$ for $\mathrm{HNO}_{3}$ and $\mathrm{NH}_{3}$, respectively), which might substantially favor the formation of $\mathrm{NH}_{4} \mathrm{NO}_{3}$.
Table 5. Comparison of temperature, $\mathrm{HNO}_{3(\mathrm{~g})}, \mathrm{NH}_{3(\mathrm{~g})}, \mathrm{NO}, \mathrm{NO}_{2}$, $\mathrm{O}_{3}$, and simulated $\mathrm{OH}$ and $\mathrm{HO}_{2}$ between episode 6 and nonepisode 2.

\begin{tabular}{|c|c|c|}
\hline & Episode 6 & Non-episode 2 \\
\hline Temperature $\left({ }^{\circ} \mathrm{C}\right)$ & $14.9 \pm 0.5$ & $17.2 \pm 0.3$ \\
\hline $\mathrm{HNO}_{3}(\mathrm{ppbv})$ & $0.65 \pm 0.01$ & $0.47 \pm 0.03$ \\
\hline $\mathrm{NH}_{3}$ (ppbv) & $13.48 \pm 0.72$ & $9.54 \pm 0.37$ \\
\hline NO (ppbv) & $43.55 \pm 11.65$ & $14.70 \pm 2.40$ \\
\hline $\mathrm{NO}_{2}$ (ppbv) & $44.93 \pm 2.29$ & $29.46 \pm 0.95$ \\
\hline $\mathrm{O}_{3}(\mathrm{ppbv})$ & $17.09 \pm 2.04$ & $24.57 \pm 1.64$ \\
\hline $\mathrm{OH}\left(\right.$ molecules $\mathrm{cm}^{-3}$ ) & $(3.8 \pm 1.3) \times 10^{5}$ & $(7.2 \pm 0.9) \times 10^{5}$ \\
\hline $\mathrm{HO}_{2}\left(\right.$ molecules $\left.\mathrm{cm}^{-3}\right)$ & $(1.1 \pm 0.3) \times 10^{7}$ & $(2.0 \pm 0.2) \times 10^{7}$ \\
\hline
\end{tabular}

Because $\mathrm{HNO}_{3(\mathrm{~g})}$ is generally formed by oxidation of $\mathrm{NO}_{x}$, the production of $\mathrm{HNO}_{3(\mathrm{~g})}$ should be closely related to the oxidative capacity of the air and the level of $\mathrm{NO}_{x}$. In episode 6 , the levels of $\mathrm{O}_{3} \quad(17.09 \pm 2.04 \mathrm{ppbv})$, $\mathrm{OH} \quad\left([3.8 \pm 1.3] \times 10^{5}\right.$ molecules $\left.\mathrm{cm}^{-3}\right), \quad$ and $\mathrm{HO}_{2}$ $\left([1.1 \pm 0.3] \times 10^{7}\right.$ molecules $\left.\mathrm{cm}^{-3}\right) \quad$ were noticeably lower than those in non-episode $2\left(\mathrm{O}_{3}\right.$, $24.57 \pm 1.64$ ppbv; OH, [7.2 \pm 0.9$] \times 10^{5}$ molecules $\mathrm{cm}^{-3}$; $\mathrm{HO}_{2}, \quad[2.0 \pm 0.2] \times 10^{7}$ molecules $\mathrm{cm}^{-3}$ ), indicating a weaker oxidative capacity. However, the levels of NO $(43.55 \pm 11.65 \mathrm{ppbv})$ and $\mathrm{NO}_{2}(44.93 \pm 2.29 \mathrm{ppbv})$ were much higher than those in non-episode $2(14.70 \pm 2.40$ and $29.46 \pm 0.95 \mathrm{ppbv}$ for $\mathrm{NO}$ and $\mathrm{NO}_{2}$, respectively), possibly leading to the enhancement of $\mathrm{HNO}_{3(\mathrm{~g})}$ in episode 6 . Furthermore, the particle-bound $\mathrm{NO}_{3}^{-}$was of low thermal stability (Querol et al., 2004), and the temperature lowered $\sim 2.3^{\circ} \mathrm{C}$ in episode 6 , which suppressed the decomposition and volatilization of $\mathrm{NH}_{4} \mathrm{NO}_{3}$. Therefore, the high levels of $\mathrm{NO}_{x}$ and $\mathrm{NH}_{3}$ and the low temperature were both responsible for the increase in $\mathrm{NO}_{3}^{-}$in episode 6 .

\subsubsection{SOC formation}

In addition to the high levels of $\mathrm{NO}_{3}^{-}$in episode 6 , the proportions of OC also increased during the autumn episodes. Because SOC is an important fraction in OC that often grows as an air mass ages, it could help to explain the increase of $\mathrm{OC}$ in the autumn episodes by exploring the possible formation mechanisms of SOC. It is well known that SOC formation is closely related to SVOCs, which are formed from the reactions with oxidative radicals (i.e., $\mathrm{RO}_{2}, \mathrm{NO}_{3}$, and $\mathrm{HO}_{2}$; Kanakidou et al., 2005; Forstner et al., 1997). Hence, the relationship between SOC and SVOCs was investigated. The SVOCs were simulated with the PBM-MCM model and SOC was calculated with the EC-tracer method mentioned in Sect. 3.2.1. The speciation of SVOCs and their precursors can be found in the Table S4 in the Supplement. Briefly, the precursors of SVOCs include isoprene, aromatics, and $\mathrm{C}_{7^{-}}$ $\mathrm{C}_{12}$ n-alkanes. 


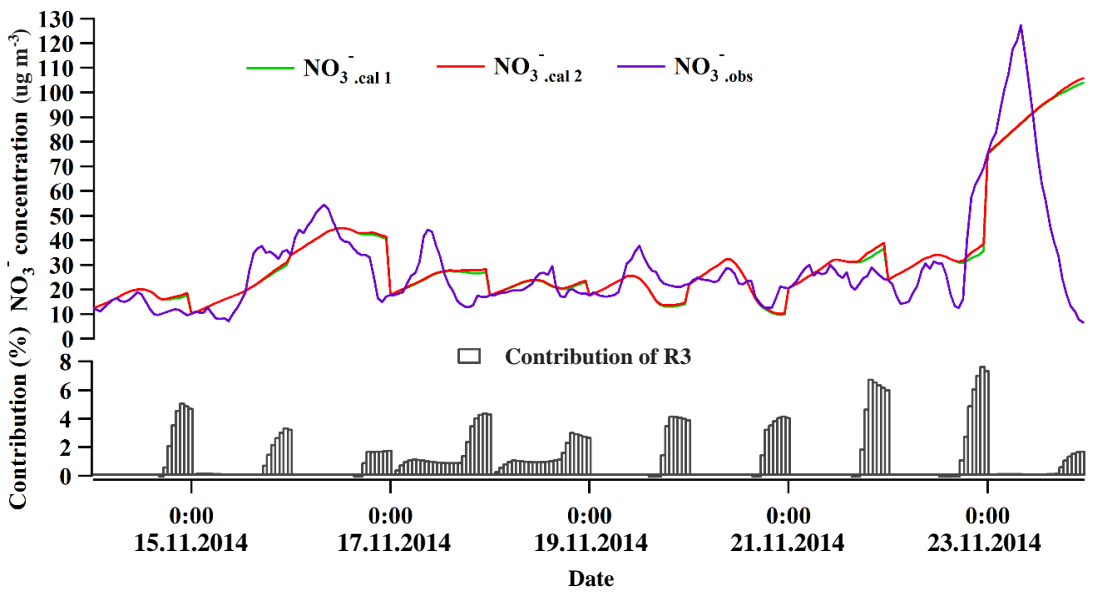

Figure 11. Comparison of $\mathrm{NO}_{3}^{-}$between theoretical calculations and observation in episode 6 .
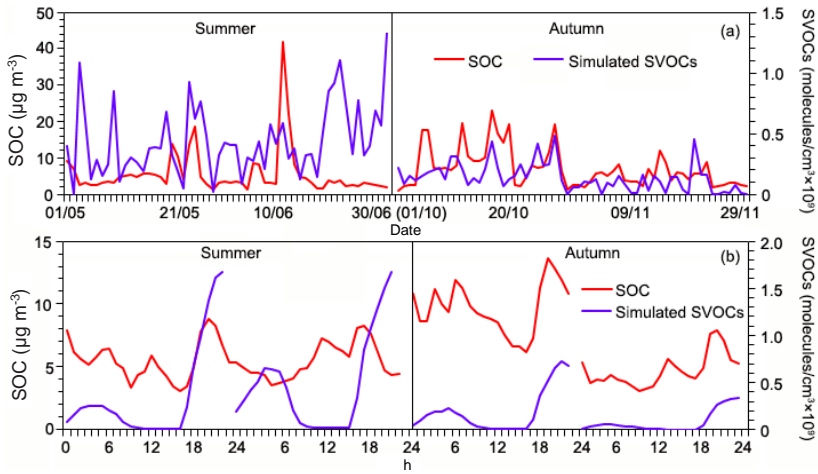

Figure 12. Correlations between calculated SOC and simulated SVOCs in (a) day-to-day variation and (b) diurnal pattern.

Figure 12 presents the daily and diurnal variations in SOC and SVOCs. It was found that SOCs correlated well with SVOCs in both daily $\left(R^{2}=0.52\right)$ and diurnal $\left(R^{2}=0.63\right)$ patterns in autumn, indicating that the simulated SVOCs were responsible for the production of SOC. The oxidation products of aromatics and isoprene were the main constituents of the SVOCs, with average contributions of $42.5 \% \pm 2.8 \%$ and $39.4 \% \pm 2.0 \%$, respectively. Among the aromatics, xylenes made the greatest contribution $(15.0 \% \pm 0.7 \%)$ to the SVOCs, followed by trimethylbenzenes $(11.5 \% \pm 0.7 \%)$, ethylbenzene $(8.8 \% \pm 0.5 \%)$, toluene $(5.1 \% \pm 0.7 \%)$, and benzene $(2.2 \% \pm 0.2 \%)$. Compared to those in non-episode 2 (i.e., $40.7 \% \pm 3.4 \%$ and $41.1 \% \pm 2.4 \%$ contributed by aromatics and isoprene, respectively), the contribution of aromatics to SVOCs increased to $46.3 \% \pm 4.1 \%$ during the episodes, whereas the proportion of isoprene oxidation products decreased to $36.1 \% \pm 3.7 \%$, suggesting that the increase in aromatics was the main cause of the autumn episodes. To quantify the contribution of biomass burning to SOC, the ob- served VOCs were apportioned to different sources, including biomass burning with $\mathrm{CH}_{3} \mathrm{CN}$ as the tracer. The source profiles are provided in Fig. S12 in the Supplement. According to the SVOCs simulated on the basis of VOCs emitted from biomass burning, the SVOCs were elevated by $15.4 \% \pm 1.3 \%$ due to biomass burning during the episodes.

In contrast, the correlations were much worse in summer $\left(R^{2}=0.01\right.$ and 0.31 for daily and diurnal variations, respectively). The high frequency $(50.8 \%)$ of rainy days in summer was a factor for the poor correlation; for example, the level of SOC was low during the late period of June when the precipitation lasted for about 10 days, and the model overestimated the SVOCs without considering the influence of precipitation. The correlations between SOC and SVOCs $\left(R^{2}=0.14\right.$ and 0.19 for the daily and diurnal variations, respectively) were still poor even after the rainy days were excluded. Hence, the poor correlation should also be related to other factors, such as incomplete consideration of the contribution of biogenic VOCs. Although isoprene was included as a precursor of the SVOCs, other biogenic species (i.e., $\alpha$ pinene, $\beta$-pinene and monoterpenes) that were proven to be important precursors of SOC (Kanakidou et al., 2005) were not monitored in this study. Moreover, the level of biogenic VOCs was much higher in summer than in autumn. Taking isoprene as an example, the mixing ratio of isoprene was $66.7 \pm 4.9 \mathrm{pptv}$ in summer and only $37.2 \pm 2.6 \mathrm{pptv}$ in autumn. The higher missing level of biogenic VOCs in summer led to a higher deficit of SVOCs, perhaps causing the poorer correlation between SOC and SVOCs. Nevertheless, this notion requires validation with more comprehensive data on biogenic VOCs. 


\section{Conclusions}

In summer and autumn 2014, the concentrations of $\mathrm{PM}_{2.5}$ and its components were continuously monitored in Wuhan; six $\mathrm{PM}_{2.5}$ episodes were captured. The analysis of $\mathrm{PM}_{2.5}$ concentrations and compositions found that Wuhan suffered from relatively high levels of $\mathrm{PM}_{2.5}$, even in the warm seasons. Secondary inorganic ions were the most predominant species in $\mathrm{PM}_{2.5}$ in the form of $\mathrm{NH}_{4} \mathrm{NO}_{3}$ and $\left(\mathrm{NH}_{4}\right)_{2} \mathrm{SO}_{4}$. Comparable levels of $\mathrm{SO}_{4}^{2-}$ and $\mathrm{NO}_{3}^{-}$indicate that stationary and mobile sources had equivalent importance in Wuhan. With the EC-tracer method, it was found that the POC level was slightly higher than that of SOC, and both increased significantly during the episodes. $\mathrm{K}$ was the most abundant element in $\mathrm{PM}_{2.5}$, implying biomass burning in and around Wuhan during the sampling campaign. Indeed, the source apportionment revealed that biomass burning was the main cause of increases in $\mathrm{PM}_{2.5}$ in episodes 1, 3, and 4. Fugitive dust was the leading factor in episode 2 . However, episodes 5 and 6 were mainly attributable to vehicle emissions and SIAs. Study of the formation mechanism of $\mathrm{NO}_{3}^{-}$and $\mathrm{SOC}$ found that $\mathrm{NO}_{3}^{-}$was mainly generated from the homogeneous reactions in episode 6 , and the high levels of $\mathrm{NO}_{x}$ and $\mathrm{NH}_{3}$ and the low temperature caused the increase in $\mathrm{NO}_{3}^{-}$. Furthermore, the daily and diurnal variations of SOC correlated well with those of SVOCs in autumn. Aromatics and isoprene were the main precursors of SOC, and the contribution of aromatics increased during the episodes. However, the correlation between SOC and SVOCs was much worse in summer, possibly as a result of the incompleteness of the biogenic VOC input in the simulation of SVOCs. This study advances our understanding of the chemical characteristics of $\mathrm{PM}_{2.5}$ in warm seasons in Wuhan and for the first time quantifies the contribution of biomass burning to $\mathrm{PM}_{2.5}$. The investigation of SOC formation will also inspire the application of the explicit chemical mechanisms on the study of SOA.

\section{Data availability}

The underlying research data were available at: https://drive.google.com/open?id=0BzLREyLa fx6WjgtVW9ZaVJOd0k.

\section{The Supplement related to this article is available online at doi:10.5194/acp-16-10671-2016-supplement.}

Acknowledgements. This study was supported by the Research Grants Council of the Hong Kong Special Administrative Region via grants PolyU5154/13E, PolyU152052/14E, CRF/C5022-14G, and CRF/C5504-15E and the Hong Kong Polytechnic University
PhD scholarships (project \#RTUP). This study is partly supported by the Hong Kong PolyU internal grant (1-ZVCX and 4-BCAV) and the National Natural Science Foundation of China (No. 41275122).

Edited by: X. Querol

Reviewed by: four anonymous referees

\section{References}

Anderson, J. O., Thundiyil, J. G., and Stolbach, A.: Clearing the air: A review of the effects of particulate matter air pollution on human health, J. Med. Toxicol., 8, 166-175, 2012.

Aumont, B., Madronich, S., Ammann, M., Kalberer, M., Baltnesperger, U., Hauglustaine, D., and Baltensperger, F.: On the $\mathrm{NO}_{2}+$ soot reaction in the atmospherem J. Geophys. Res.m 104, 1729-1736, 1999.

Barwise, A. J. G.: Role of nickel and vanadium in petroleum classification, Energ. Fuel., 4, 647-652, 1990.

Brown, S. G., Frankel, A., and Hafner, H. R.: Source apportionment of VOCs in Los Angeles area using positive matrix factorization, Atmos. Environ., 41, 227-237, 2007.

Cabada, J. C., Pandis, S. N., Subramanian, R., Robinson, A. L., Polidori, A., and Turpin, B.: Estimating the secondary organic aerosol contribution to $\mathrm{PM}_{2.5}$ using the $\mathrm{EC}$ tracer method, Aerosol Sci. Tech., 38, 140-155, 2004.

Cao, J. J., Wu, F., Chow, J. C., Lee, S. C., Li, Y., Chen, S. W., An, Z. S., Fung, K. K., Watson, J. G., Zhu, C. S., and Liu, S. X.: Characterization and source apportionment of atmospheric organic and elemental carbon during fall and winter of 2003 in Xi'an, China, Atmos. Chem. Phys., 5, 3127-3137, doi:10.5194/acp-53127-2005, 2005.

Cao, J. J., Shen, Z. X., Chow, J. C., Watson, J. G., Lee, S. C., Tie, X. X., Ho, K. F., Wang, G. H., and Han, Y. M.: Winter and summer $\mathrm{PM}_{2.5}$ chemical compositions in fourteen Chinese cities, J. Air Waste Manage., 62, 1214-1226, 2012.

Cheng, H. R., Guo, H., Wang, X. M., Saunders, S. M., Lam, S. H. M., Jiang, F., Wang, T. J., Ding, A. J., Lee, S. C., and Ho, K. F.: On the relationship between ozone and its precursors in the Pearl River Delta: application of an observation-based model (OBM), Environ. Sci. Pollut. Res., 17, 547-560, 2010.

Cheng, H. R., Gong, W., Wang, Z. W., Zhang, F., Wang, X. M., Lv, X. P., Liu, J., Fu, X. X., and Zhang, G.: Ionic composition of submicron particles $\left(\mathrm{PM}_{1.0}\right)$ during the long-lasting haze period in January 2013 in Wuhan, central China, J. Environ. Sci., 26, 810-817, 2014.

Chow, J. C., Watson, J. G., Lu, Z. Q., Lowenthal, D. H., Frazier, C. A., Solomon, P. A., Thuillier, R. H., and Magliano, K.: Descriptive analysis of $\mathrm{PM}_{2.5}$ and $\mathrm{PM}_{10}$ at regionally representative locations during SJVAQS/AUSPEX, Atmos. Environ., 30, 2079_ 2112, 1996.

Deng, X. J., Tie, X. X., Zhou, X. J., Wu, D., Zhong, L. J., Tan, H. B., Li, F., Huang, X. Y., Bi, X. Y., and Deng, T.: Effects of Southeast Asia biomass burning on aerosols and ozone concentrations over the Pearl River Delta (PRD) region, Atmos. Environ., 43, 84938501, 2008. 
Deng, X. J., Li, F., Li, Y. H., Li, J. Y., Huang, H. Z., and Liu, X. T.: Vertical distribution characteristics of PM in the surface layer of Guangzhou, Particuology, 20, 3-9, 2015.

Duan, F. K., He, K. B., Ma, Y. L., Jia, Y. T., Yang, F. M., Lei, Y., Tanaka, S., and Okuta, T.: Characteristics of carbonaceous aerosols in Beijing, China, Chemosphere, 60, 355-364, 2005.

Echalar, F., Gaudichet, A., Cachier, H., and Artaxo, P.: Aerosol emissions by tropical forest and savanna biomass burning: characteristic trace elements and fluxes, Geophys. Res. Lett., 22, 3039-3042, 1995.

Emmerson, K. M., Carslaw, N., Carpenter, L. J., Heard, D. E., Lee, J. D., and Pilling, M. J.: Urban atmospheric chemistry during the PUMA campaign 1: Comparison of modelled $\mathrm{OH}$ and $\mathrm{HO}_{2}$ concentrations with measurements, J. Atmos. Chem., 52, 143164,2005

Forstner, H. J. L., Flagan, R. C., and Seinfeld, J. H.: Secondary organic aerosol from the photooxidation of aromatic hydrocarbons: molecular composition, Environ. Sci. Technol., 31, 1345-1358, 1997.

Friedli, H. R., Radke, L. F., Lu, J. Y., Banic, C. M., Leaitch, W. R., and MacPherson, J. I.: Mercury emissions from burning of biomass from temperate North American forests: laboratory and airborne measurements, Atmos. Environ., 37, 253-267, 2003.

GB 3095-2012: available at: http://kjs.mep.gov.cn/hjbhbz/bzwb/ dqhjbh/dqhjzlbz/201203/W020120410330232398521.pdf, last access: 1 August 2016.

Geng, F. H., Zhang, Q., Tie, X. X., Huang, M. Y., Ma, X. C., Deng, Z. Z., Yu, Q., Quan, J. N., and Zhao, C. S.: Aircraft measurements of $\mathrm{O}_{3}, \mathrm{NO}_{x}, \mathrm{CO}$, VOCs, and $\mathrm{SO}_{2}$ in the Yangtze River Delta region, Atmos. Environ., 43, 584-593, 2009.

Goldberg, M. S., Burnett, R. T., Bailar III, J. C., Brook, J., Bonvalot, Y., Tamblyn, R., Singh, R., and Valois, M. F.: The association between daily mortality and ambient air particle pollution in Montreal, Quebec: 1. Nonaccidental mortality, Environ. Res., 86, 12-25, 2001.

Grigoratos, T. and Martini, G.: Brake wear particle emissions: a review, Environ. Sci. Pollut. Res., 22, 2491-2504, 2015.

Gugamsetty, B., Wei, H., Liu, C. N., Awasthi, A., Hsu, S. C., Tsai, C. J, Roan, G. D., Wu, Y. C., and Chen, C. F.: Source Characterization and Apportionment of $\mathrm{PM}_{10}, \mathrm{PM}_{2.5}$ and $\mathrm{PM}_{0.1}$ by Using Positive Matrix Factorization, Aerosol Air Qual. Res., 12, 476491, 2012.

Guo, H., Zou, S. C., Tsai, W. Y., Chan, L. Y., and Blake, D. R.: Emission characteristics of nonmethane hydrocarbons from private cars and taxis at different driving speeds in Hong Kong, Atmos. Environ., 45, 2711-2721, $2011 \mathrm{a}$.

Guo, H., Cheng, H. R., Ling, Z. H., Louie, P. K. K., and Ayoko, G. A.: Which emission sources are responsible for the volatile organic compounds in the atmosphere of Pearl River Delta?, J. Hazard. Mater., 188, 116-124, 2011b.

HKEPD: Air Quality in Hong Kong 2014, available at: http://www.aqhi.gov.hk/en/download/air-quality-reportse469. html?showall=\&start=1 (last access: 1 August 2016), 2014.

$\mathrm{Hu}$, J. H. and Abbatt, J. P. D.: Reaction probabilities for $\mathrm{N}_{2} \mathrm{O}_{5}$ hydrolysis on sulfur acid and ammonium sulfate aerosols at room temperature, J. Phys. Chem. A, 101, 871-878, 1997.

Kanakidou, M., Seinfeld, J. H., Pandis, S. N., Barnes, I., Dentener, F. J., Facchini, M. C., Van Dingenen, R., Ervens, B., Nenes, A., Nielsen, C. J., Swietlicki, E., Putaud, J. P., Balkanski, Y., Fuzzi,
S., Horth, J., Moortgat, G. K., Winterhalter, R., Myhre, C. E. L., Tsigaridis, K., Vignati, E., Stephanou, E. G., and Wilson, J.: Organic aerosol and global climate modelling: a review, Atmos. Chem. Phys., 5, 1053-1123, doi:10.5194/acp-5-1053-2005, 2005.

Kanaya, Y., Sadanaga, Y., Matsumoto, J., Sharma, U. K., Hirokawa, J., Kajii, Y., and Akimoto, H.: Nighttime observation of the $\mathrm{HO}_{2}$ radical by an LIF instrument at Oki Island, Japan, and its possible origins, Geophys. Res. Lett., 26, 2179-2182, 1999.

Kang, H. Q., Zhu, B., Su, J. F., Wang, H. L., Zhang, Q. C., and Wang, F.: Analysis of a long-lasting haze episode in Nanjing, China, Atmos. Res., 120-121, 78-87, 2013.

Kerminen, V. M., Hillamo, R., Teinila, K., Pakkanen, T., Allegrini, I., and Sparapani, R.: Ion balances of size-resolved tropospheric aerosol samples: implications for the acidity and atmospheric processing of aerosols, Atmos. Environ., 35, 5255-5265, 2001.

Koe, L. C. C., Arellano, A. F., and McGregor, J. L.: Investigating the haze transport from 1997 biomass burning in Southeast Asia: its impact upon Singapore, Atmos. Environ., 35, 2723-2734, 2001.

Lam, S. H. M., Saunders, S. M., Guo, H., Ling, Z. H., Jiang, F., Wang, X. M., and Wang, T. J.: Modelling VOC source impacts on high ozone episode days observed at a mountain summit in Hong Kong under the influence of mountain-valley breezes, Atmos. Environ., 81, 166-176, 2013.

Lee, E., Chan, C. K., and Paatero, P.: Application of positive matrix factorization in source apportionment of particulate pollutants in Hong Kong, Atmos. Environ., 33, 3201-3212, 1999.

Lin, Y. C., Cheng, M. T., Lin, W. H., Lan, Y. Y., and Tsuang, B. J.: Causes of the elevated nitrated aerosol levels during episodic days in Taichung urban area, Taiwan, Atmos. Environ., 44, 1632 1640, 2010.

Ling, Z. H., Guo, H., Lam, S. H. M., Saunders, S. M., and Wang, T.: Atmospheric photochemical reactivity and ozone production at two sites in Hong Kong: Application of a master chemical mechanism-photochemical box model, J. Geophys. Res.Atmos., 119, 10567-10582, 2014.

Liu, Y. J., Zhang, T. T., Liu, Q. Y., Zhang, R. J., Sun, Z. Q., and Zhang, M. G.: Seasonal variation of physical and chemical properties in TSP, $\mathrm{PM}_{10}$ and $\mathrm{PM}_{2.5}$ at a roadside site in Beijing and their influence on atmospheric visibility, Aerosol Air Qual. Res., 14, 954-969, 2014.

Liu, Z. R., Hu, B., Wang, L. L., Wu, F. K., Gao, W. K., and Wang, Y. S.: Seasonal and diurnal variation in particulate matter $\left(\mathrm{PM}_{10}\right.$ and $\mathrm{PM}_{2.5}$ ) at an urban site of Beijing: analyses from a 9-year study, Environ. Sci. Pollut. Res., 22, 627-642, 2015.

Lyu, X. P., Wang, Z. W., Cheng, H. R., Zhang, F., Zhang, G., Wang, X. M., Ling, Z. H., and Wang, N.: Chemical characteristics of submicron particulates $\left(\mathrm{PM}_{1.0}\right)$ in Wuhan, Central China, Atmos. Res., 161-162, 169-178, 2015a.

Lyu, X. P., Ling, Z. H., Guo, H., Saunders, S. M., Lam, S. H. M., Wang, N., Wang, Y., Liu, M., and Wang, T.: Re-examination of $\mathrm{C}_{1}-\mathrm{C}_{5}$ alkyl nitrates in Hong Kong using an observation-based model, Atmos. Environ., 120, 28-37, 2015b.

Lyu, X. P., Chen, N., Guo, H., Zhang, W. H., Wang, N., Wang, Y., and Liu, M.: Ambient volatile organic compounds and their effect on ozone production in Wuhan, central China, Sci. Total Environ., 541, 200-209, 2016. 
NASA: FIRMS Web Fire Mapper 2014, available at: https://firms. modaps.eosdis.nasa.gov/firemap/ (last access: 1 August 2016), 2014.

Nemesure, S., Wagener, R., and Schwartz, S. E.: Direct shortwave forcing of climate by the anthropogenic sulfate aerosol: sensitivity to particle size, composition, and relative humidity, J. Geophys. Res., 100, 26105-26116, 1995.

Nriagu, J. O. and Pacyna, J. M.: Quantitative assessment of worldwide contamination of air, water and soils by trace metals, Nature, 333, 134-139, 1988.

Oanh, N. T. K. and Leelasakultum, K.: Analysis of meteorology and emission in haze episode prevalence over mountain-bounded region for early warning, Sci. Total Environ., 409, 2261-2271, 2011.

Paatero, P.: Least squares formulation of robust non-negative factor analysis, Chemom. Intell. Lab. Sys., 37, 23-35, 1997.

Paatero, P. and Tapper, U.: Positive matrix factorization: A nonnegative factor model with optimal utilization of error estimates of data values, Environmetrics, 5, 111-126, 1994.

Pathak, R. K., Wang, T., and Wu, W. S.: Nighttime enhancement of $\mathrm{PM}_{2.5}$ nitrate in ammonia-poor atmospheric conditions in Beijing and Shanghai: Plausible contributions of heterogeneous hydrolysis of $\mathrm{N}_{2} \mathrm{O}_{5}$ and $\mathrm{HNO}_{3}$ partitioning, Atmos. Environ., 45, 1183-1191, 2011.

Querol, X., Alastuey, A., Viana, M. M., Rodriguez, S., Artinano, B., Salvador, P., Garcia do Santos, S., Fernandez Patier, R., Ruiz, C. R., de la Rosa, J., Sanchez de la Campa, A., Menendez, M., and Gil, J. I.: Speciation and origin of $\mathrm{PM}_{10}$ and $\mathrm{PM}_{2.5}$ in Spain, J. Aerosol Sci., 35, 1151-1172, 2004.

Ramanathan, V., Crutzen, P. J., Kiehl, J. T., and Rosenfeld, D.: Aerosol, climate and the hydrological cycle, Science, 294, 21192124, 2001.

Saarikoski, S., Sillanpaa, M., Sofiev, M., Timonen, H., Saarnio, K., Teinila, K., Karppinen, A., Kukkonen, J., and Hillamo, R.: Chemical composition of aerosols during a major biomass burning episode over northern Europe in spring 2006: Experimental and modelling assessments, Atmos. Environ., 41, 3577-3589, 2007.

Seinfeld, J. H. and Pandis, S. N.: Atmospheric chemistry and physics from air pollution to climate change, New York, Wiley, 528 pp., 1998.

Shen, G. F., Yuan, S. Y., Xie, Y. N., Xia, S. J., Li, L., Yao, Y. K., Qiao, Y. Z., Zhang, J., Zhao, Q. Y., Ding, A. J., Li, B., and Wu, H. S.: Ambient levels and temporal variations of $\mathrm{PM}_{2.5}$ and $\mathrm{PM}_{10}$ at a residential site in the mega-city, Nanjing, in the western Yangtze River Delta, China, J. Environ. Sci. Heal. A, 49, 171178, 2014.

Simoneit, B. R. T.: Biomass burning-a review of organic tracers for smoke from incomplete combustion, Appl. Geochem., 17, 129$162,2002$.

Song, S., Wu, Y., Jiang, J., Yang, L., Cheng, Y., and Hao, J.: Chemical characteristics of size-resolved $\mathrm{PM}_{2.5}$ at a roadside environment in Beijing, China, Environ. Pollut., 161, 215-221, 2012.

Takekawa, H., Minoura, H., and Yamazaki, S.: Temperature dependence of secondary organic aerosol formation by photo-oxidation of hydrocarbons, Atmos. Environ., 37, 3413-3424, 2003.

Tang, I. N. and Munkelwitz, H. R.: Compositions and temperature dependence of the deliquescence properties of hygroscopic aerosols, Atmos. Environ., 27, 467-473, 1993.
Theodosi, C., Grivas, G., Zarmpas, P., Chaloulakou, A., and Mihalopoulos, N.: Mass and chemical composition of sizesegregated aerosols $\left(\mathrm{PM}_{1}, \mathrm{PM}_{2.5}, \mathrm{PM}_{10}\right)$ over Athens, Greece: local versus regional sources, Atmos. Chem. Phys., 11, 1189511911, doi:10.5194/acp-11-11895-2011, 2011.

Wang, H., Tan, S. C., Wang, Y., Jiang, C., Shi, G. Y., Zhang, M. X., and Che, H. Z.: A multisource observation study of the severe prolonged regional haze episode over eastern China in January 2013, Atmos. Environ., 89, 807-815, 2014a.

Wang, H., Xu, J. Y., Zhang, M., Yang, Y. Q., Shen, X. J., Wang, Y. Q., Chen, D., and Guo, J. P.: A study of the meteorological causes of a prolonged and severe haze episode in January 2013 over central-eastern China, Atmos. Environ., 98, 146-157, 2014 b.

Wang, H. L., Lou, S. R., Huang, C., Qiao, L. P., Tang, X. B., Chen, C. H., Zeng, L. M., Wang, Q., Zhou, M., Lu, S. H., and Yu, X. N.: Source profiles of volatile organic compounds from biomass burning in Yangtze River Delta, China, Aerosol Air Qual. Res., 14, 818-828, 2014.

Wang, J., Hu, Z. M., Chen, Y. Y., Chen, Z. L., and Xu, S. Y.: Contamination characteristics and possible sources of $\mathrm{PM}_{10}$ and $\mathrm{PM}_{2.5}$ in different functional areas of Shanghai, China, Atmos. Environ., 68, 221-229, 2013.

Wang, P., Cao, J. J., Tie, X. X., Wang, G. H., Li, G. H., Hu, T. F., Wu, Y. T., Xu, Y. S., Xu, G. D., Zhao, Y. Z., Ding, W. C., Liu, H. K., Huang, R. J., and Zhan, C. L.: Impact of meteorological parameters and gaseous pollutants on $\mathrm{PM}_{2.5}$ and $\mathrm{PM}_{10}$ mass concentrations during 2010 in Xi'an, China, Aerosol Air Qual. Res., 15, 1844-1854, 2015.

Wang, S. X., Zhang, L., Li, G. H., Wu, Y., Hao, J. M., Pirrone, N., Sprovieri, F., and Ancora, M. P.: Mercury emission and speciation of coal-fired power plants in China, Atmos. Chem. Phys., 10, 1183-1192, doi:10.5194/acp-10-1183-2010, 2010.

Wang, Y. X., Zhang, Q. Q., Jiang, J. K., Zhou, W., Wang, B. Y., He, K. B., Duan, F. K., Zhang, Q., Philip, S., and Xie, Y. Y.: Enhanced sulfate formation during China's severe winter haze episode in January 2013 missing from current models, J. Geophys. Res., 119, 10425-10440, 2014.

White, W. H. and Roberts, P. T.: On the nature and origins of visibility-reducing aerosols in the Los Angeles air basin, Atmos. Environ. 11, 803-812, 1977.

Wuhan Environmental Bulletin: available at: http://www.whepb. gov.cn/zwGkhjtj/16240.jhtml (last access: 1 August 2016), 2014.

Yang, L., Cheng, S., Wang, X., Nie, W., Xu, P., Gao, X., Yuan, C., and Wang, W.: Source identification and health impact of $\mathrm{PM}_{2.5}$ in a heavily polluted urban atmosphere in China, Atmos. Environ., 75, 265-269, 2013.

Yang, L. X., Zhou, X. H., Wang, Z., Zhou, Y., Cheng, S. H., Xu, P. J., Gao, X. M., Nie, W., Wang, X. F., and Wang, W. X.: Airborne fine particulate pollution in Jinan, China: Concentrations, chemical compositions and influence on visibility impairment, Atmos. Environ., 55, 506-514, 2012.

Yao, X. H., Chan, C. K., Fang, M., Candle, S., Chan, T., Mulawa, P., He, K. B., and Ye, B.: The water-soluble ionic composition of $\mathrm{PM}_{2.5}$ in Shanghai and Beijing, China, Atmos. Environ., 36, 4223-4234, 2002.

Ye, B., Ji, X., Yang, H., Yao, X., Chan, C. K., Cadle, S. H., Chan, T., and Mulawa, P. A.: Concentration and chemical composition of $\mathrm{PM}_{2.5}$ in Shanghai for a 1-year period, Atmos. Environ., 37, 499-510, 2003. 
Zhang, F., Cheng, H. R., Wang, Z. W., Lv, X. P., Zhu, Z. M., Zhang, G., and Wang, X. M.: Fine particles $\left(\mathrm{PM}_{2.5}\right)$ at a CAWNET background site in Central China: Chemical compositions, seasonal variations and regional pollution events, Atmos. Environ., 86, 193-202, 2014.

Zhang, G. H., Bi, X. H., Chan, L. Y., Wang, X. M., Sheng, G. Y., and Fu, J. M.: Size-segregated chemical characteristics of aerosol during haze in an urban area of the Pearl River Delta region, China, Urban Climate, 4, 74-84, 2013.

Zhang, Q., Jimenez, J. L., Worsnop, D. R., and Canagaratna, M.: A case study of urban particle acidity and its influence on secondary organic aerosol, Environ. Sci. Technol., 41, 3213-3219, 2007.

Zhang, X. Y., Wang, Y. Q., Niu, T., Zhang, X. C., Gong, S. L., Zhang, Y. M., and Sun, J. Y.: Atmospheric aerosol compositions in China: spatial/temporal variability, chemical signature, regional haze distribution and comparisons with global aerosols, Atmos. Chem. Phys., 12, 779-799, doi:10.5194/acp12-779-2012, 2012.
Zhang, Y. Y., Obrist, D., Zielinska, B., and Gertler, A.: Particulate emissions from different types of biomass burning, Atmos. Environ., 72, 27-35, 2013.

Zheng, M., Salmon, L. G., Schauer, J. J., Zeng, L. M., Kiang, C. S., Zhang, Y. H., and Cass, G. R.: Seasonal trends in $\mathrm{PM}_{2.5}$ source contributions in Beijing, China, Atmos. Environ., 39, 3967-3976, 2005. 